\title{
Comparison of mineral contents of popular fruit and vegetable varieties in korea
}

\author{
Sun-kyung Lee*, Soo-Hyun Ji, You-Seok Lee, Gyeong-Suk Jo, Jeong-Hwa Kang \\ Jellanamdo Agricultural Research and Extension Services, Naju 58213, Korea
}

\section{한국인 선호 과채류 품종별 무기질 함량 비교}

\author{
이선경*·지수현·이유석·조경숙·강정화 \\ 전라남도농업기술원 친환경농업연구소
}

\begin{abstract}
This study investigated the mineral content of regularly consumed Korean produce in order to provide a basis for informed decisions regarding a balanced diet. Eleven minerals prevalent in the produce were analyzed by microwave digestion coupled with ICP-OES and ICP-MS. In general, vegetables showed a higher mineral content than fruits, with Daekwonseoneon peppers providing th highest values for $\mathrm{P}, \mathrm{K}$, and $\mathrm{Mg}$ among the 52 varieties of fruits and vegetables examined $(79.57 \mathrm{mg} / 100 \mathrm{~g}, 638.59 \mathrm{mg} / 100 \mathrm{~g}$ and $37.30 \mathrm{mg} / 100 \mathrm{~g}$, respectively). Among the 35 fruit varieties analyzed, Geumsil strawberies delivered the highest contents of $\mathrm{Ca}, \mathrm{P}, \mathrm{Mg}, \mathrm{Fe}, \mathrm{Mn}$, and $\mathrm{Mo}(23.52 \mathrm{mg} / 100$ $\mathrm{g}, 45.29 \mathrm{mg} / 100 \mathrm{~g}, 20.05 \mathrm{mg} / 100 \mathrm{~g}, 0.87 \mathrm{mg} / 100 \mathrm{~g}, 0.58 \mathrm{mg} / 100 \mathrm{~g}, 8.44 \mu \mathrm{g} / 100 \mathrm{~g}$, respectively). High Ca and $K$ contents were observed in grapes, particularly those of the Shine Muscat varieties $(12.28 \mathrm{mg} / 100 \mathrm{~g}$ and 241.42 $\mathrm{mg} / 100 \mathrm{~g}$, respectively) and Jico tomato varieties contained the highest $\mathrm{Na}$ content $(10.82 \mathrm{mg} / 100 \mathrm{~g})$. Moreover, notable macro-mineral content was detected in nectarine (Cheonhong, Sunfre, and Fantasia) and baekdo (Cheonjungdo) peach varieties. Apples provided both macro-minerals autumn apples; Jahong, Arisoo, and Hongro and micro-minerals summer apple; SummerKing and Tsugaru with diverse mineral content in same varieties depending on the cultivation area. Based on our findings, a balanced diet containing the necessary contents of macro and micro-minerals can be easily achieved by varying the type and variety of regularly consumed produce.
\end{abstract}

Key words : fruit, vegetable, varieties, region, minerals

\section{서 론}

식품의 역할은 궁극적으로 인체에 필요한 영양성분의 공급을 위한 것으로 건강의 유지와 증진을 목적으로 그 역할이 확대되고 있어, 국가에서는 식량, 영양 및 건강 정책 을 수립하고 단체급식 식단을 작성하는 등 소비자들에게 건강하고 균형된 식생활을 영위할 수 있도록 식품에 대한 기본 영양정보를 제 공하는 것이 필요하다 $(1,2)$. 우리나라에

*Corresponding author. E-mail : sklee10@korea.kr Phone : 82-61-330-2514, Fax : 82-61-336-4076

Received 10 September 2019; Revised 26 September 2019; Accepted 04 October 2019.

Copyright (c) The Korean Society of Food Preservation. All rights reserved.
서는 1970년 UN의 FAO/WTO에서 지원하는 한국응용영양 사업의 일환인 국내 · 외 영양정보 식품성분표 발간을 시작 으로 2011년 제8개정판에 이르기까지 22개 성분 위주로 발간되어 왔다. 그러나 영양성분 범위 확대 및 식품성분표 의 활용도 제고를 위해 국민 다소비 식품 위주의 체계적인 시료 선정의 필요성이 제기되고 있어 제9개정판 발간을 시작으로 새롭게 식품성분 DB 구축을 추진하고 있다 $(2,6)$ 또한 최근 우리나라 생활수준의 향상은 식생활에도 많은 변화를 가져와 건강에 대한 관심이 높아져 탄수화물, 단백 질, 지방의 3 대 영양소 이외에 비타민, 무기질과 같은 미량 영양소가 주목받고 있다(3). 이에 따라 미량영양성분의 효 율성 제고를 위하여 더 세분화 된 국가식품영양성분표로 분리하여 발간되고 있으며 더불어 미량영양소의 급원인 채소와 과일은 현대인의 식탁에서 중요한 위치를 차지하고 
있다 $(4,5)$.

미량영양소의 하나인 무기질(Minerals)은 식품이나 생체 에 함유되어 있는 원소 가운데 $\mathrm{C}, \mathrm{H}, \mathrm{O}, \mathrm{N}$ 을 제외한 다른 원소를 통틀어 지칭하며, 식품을 태운 후 재로 남으므로 회분(Ash)이라고도 정의한다. 이는 에너지원은 아니지만 매우 중요한 생물체의 구성 성분으로 생체 내에서 체조직 형성, $\mathrm{pH}$ 조절을 통한 완충작용, 신경과 근육의 조절작용 그리고 여러 가지 효소의 구성성분으로 중요한 생리적 기능 을 유지하는 등 다양한 역할을 담당하고 있어 일정량의 섭취가 반드시 요구되며 섭취가 부족하면 결핍증이 나타난 다(6).

이렇게 인간에게 없어서는 안 될 중요한 무기질에 대한 연구로는 현재까지 영양강화식품(1,3,7), 가공식품(12) 및 유통음료(8), 곡류(백미, 현미, 쌀보리, 겉보리, 밀 등) $(10,11,14)$, 각종 농산물(엽채류, 근채류, 감, 호박 등)의 조리 방법, 수확시기 및 저장방법(13,15-17)에 따른 무기질 함량 등에 관한 연구가 있다. 과일 및 열매채소에 대한 연구는 $\operatorname{Kim}$ 등(9)의 사과 4 가지 품종(뉴조나골드, 홍옥, 아오리, 후지)과 유통 사과주스의 무기질 함량에 관한 연구, $\mathrm{Kim}$ 등(5)의 과일과 채소 단일 품종의 계정에 따른 무기질 함량 비교 연구, Ji 등(4)의 단일 품종의 곡류와 채소류, 소빈도 과일(키위, 감, 아로니아)의 품종별 무기질 함량을 비교한 것으로 한국인들의 다빈도 섭취 과일과 채소류의 품종별 무기질 함량에 대한 연구는 아직 미흡하다.

따라서 본 연구에서는 미량영양소의 중요한 급원의 하나 인 채소와 과일 중 최근 소비가 점차 증가하고 있는 품목을 국민건강영양조사의 다소비 항목과 다빈도 순위, 식품소비 행태조사 기초분석보고서 및 선행연구를 토대로 선정하고 (26-29), 각 품목에 대한 품종별, 그 중 선호 1 위 품목인 사과는 동일품종에 대한 재배지역별로 무기질 중 $\mathrm{Ca}, \mathrm{P}$, $\mathrm{Na}, \mathrm{K}, \mathrm{Mg}, \mathrm{Fe}, \mathrm{Mn}, \mathrm{Zn}, \mathrm{Cu}, \mathrm{Mo}, \mathrm{Se}$ 함량을 비교 · 분석하여 과채류의 품종별 차이에 대한 정보를 제시함으로써 소비자 들의 균형된 식생활 영위를 위한 기본 영양정보를 제공하고 자 하였다.

\section{재료 및 방법}

\section{실험재료}

본 연구에 사용된 시료는 국가표준식품성분표 발간 및 식품성분 $\mathrm{DB}$ 구축을 위한 것으로 영양성분은 재배조건 및 품종에 따라 변화가 크기 때문에 생산지, 생산량, 생산시 기를 고려하여 각 지역별로 품목에 따른 품종의 적정 시료 를 선정하였다. 시료는 딸기 등 과일류 품종별 35 개, 토마토 등 채소류 품종별 17 개로 8 개 도 농업기술원(강원, 경기, 충북, 충남, 전북, 전남, 경북, 경남)에서 수집하고, 농촌진흥 청 국립농업과학원 식생활영양과에서 전처리한 시료를 제
공받아 냉동고 $\left(-20^{\circ} \mathrm{C}\right)$ 에 보관하면서 분석에 사용하였다.

\section{시약 및 장치}

무기질 분석방법의 검증 및 분석 데이터의 신뢰도를 높 이기 위해 분석 시 본 연구에 사용된 Standard Reference Materia 1(SRM) 3252 및 SRM 1849a는 National Institute of Standards \& Technology(NIST, Gaithersburg, MD, USA) 에서 구입하여 사용하였다. 시료의 분해를 위해 사용한 질 산은 EP-S(Electronic grade, Dong Woo Fine Chem., Seoul, Korea)이었고, 11 종의 무기질 표준품 $(\mathrm{Ca}, \mathrm{P}, \mathrm{K}, \mathrm{Na}, \mathrm{Mg}$, $\mathrm{Fe}, \mathrm{Zn}, \mathrm{Cu}, \mathrm{Mn}, \mathrm{Se}, \mathrm{Mo}$ )은 AccuStandard(AccuStandard, Inc., Newhaven, CT, USA)에서 판매하는 ICP standard 1,000 $\mu$ $\mathrm{g} / \mathrm{mL}$ 농도의 $100 \mathrm{~mL}$ 표준원액 제품을 각각 구입하여 사용 하였다.

시료의 분해 장치는 Microwave Digestion System (C-9000, Ctrl-M Scientific Co., CA, USA)을 이용하였고, $\mathrm{Ca}, \mathrm{P}, \mathrm{K}, \mathrm{Na}, \mathrm{Mg}, \mathrm{Fe}, \mathrm{Zn}, \mathrm{Cu}$ 의 분석은 Inductively Coupled Plasma-Optical Emission Spectrometer(ICP-OES, Optima $7300 \mathrm{DV}$, Perkin Elmer, CT, USA), $\mathrm{Se}, \mathrm{Mo}$ 의 분석은 Inductively Coupled Plasma Spectrometer Mass(ICP-MS, 7900, Agilent Technologies, Inc., Tokyo, Japan)를 이용하여 측정하였다.

\section{표준용액의 조제}

각각의 표준원액 $(1,000 \mu \mathrm{g} / \mathrm{mL})$ 을 $2 \%$ 질산을 이용하여 희석하였으며, 다량 무기질 $(\mathrm{Ca}, \mathrm{P}, \mathrm{K}, \mathrm{Na}, \mathrm{Mg})$ 은 $100 \mathrm{\mu g} / \mathrm{mL}$, 미량 무기질 $(\mathrm{Fe}, \mathrm{Zn}, \mathrm{Cu}, \mathrm{Mn})$ 은 $10 \mu \mathrm{g} / \mathrm{mL}$, 초미량 무기질 (Se, Mo)은 $100 \mathrm{ng} / \mathrm{mL}$ 으로 희석한 후 각각 혼합표준용액을 조제하고 다량 무기질은 $1,5,10,50,100 \mathrm{\mu g} / \mathrm{mL}$, 미량 무기 질은 $0.01,0.05,0.1,0.5,1,10 \mu \mathrm{g} / \mathrm{mL}$, 초미량 무기질은 $1,5,10,50,100 \mathrm{ng} / \mathrm{mL}$ 의 농도로 조제하여 표준용액으로 사용하였다.

\section{시료의 전처리}

시료는 1 차 수돗물, 2 차 증류수를 이용하여 세척하고 물기를 제거한 후 가식부만 분리하여 가로, 세로, 높이가 각 $1.5 \mathrm{~cm}$ 미만이 되도록 세절하였다. 세절된 시료는 액체질 소로 급속 동결한 뒤 마쇄하고 균질화하여 전처리하였다.

\section{무기질 분석}

무기질 분석의 시험용액은 식품공전 습식분해 마이크로 웨이브법에 준하여 조제하였다(18). 즉, 시료 약 0.3-0.7 g(분 말시료 $0.3 \mathrm{~g}$, 액체시료 $0.7 \mathrm{~g}$ )을 microwave 분해용 테프론 튜브(RXHP-L1, Ctrl-M Scientific Co., CA, USA)에 넣고 질산 $7 \mathrm{~mL}$ 를 가하여 약 1 시간 이상 방치 후 microwave를 사용하여 Table 1 의 조건으로 분해하였다. 분해된 시료는 $50 \mathrm{~mL}$ 정용플라스크에 옮겨 3차 증류수(Milli Q Reference 
A+ Elix, Millipore, MA, USA) 이용)로 정용하고, Whatman No. 41 여과지(Ashless, Diameter $150 \mathrm{~mm}$, Buckinghamchire, $\mathrm{UK})$ 로 여과하여 무기질 분석의 시험용액으로 사용하였다. 11 종의 무기질 중 $\mathrm{Ca}, \mathrm{P}, \mathrm{K}, \mathrm{Na}, \mathrm{Mg}, \mathrm{Fe}, \mathrm{Zn}, \mathrm{Cu}, \mathrm{Mn}$ 는 $\mathrm{ICP}-\mathrm{OES}$ 를 이용하여 분석하였고, 측정 시 사용한 파장은 Ca 317.933 nm, P 213.617 nm, K 766.490 nm, Na 589.592 nm, Mg 285.213 nm, Fe 238.204 nm, Zn 206.200 nm, Cu $327.393 \mathrm{~nm}, \mathrm{Mn} 257.610 \mathrm{~nm}$ 이었으며, Se 및 Mo은 ICP-MS 를 사용하여 분석하였고, ICP-OES와 ICP-MS 기기분석 조 건은 Table 2와 같다.

Table 1. Operation conditions of microwave digestion system

\begin{tabular}{ccccc}
\hline Step & Temperature $\left({ }^{\circ} \mathrm{C}\right)$ & Ramp time $(\mathrm{min})$ & Hold time $(\mathrm{min})$ & Power $(\mathrm{W})$ \\
\hline 1 & 100 & 10 & 5 & \\
2 & 130 & 10 & 5 & 1,800 \\
3 & 170 & 10 & 10 & \\
4 & 0 & 0 & 20 & \\
\hline
\end{tabular}

Table 2. Operation conditions of ICP-OES \& ICP-MS

\begin{tabular}{ccc}
\hline & Parameter & Value \\
\hline \multirow{3}{*}{ ICP-OES } & RF power (W) & 1,300 \\
& Nebulizer pump (rps) & 0.55 \\
& Nebulizer pump flow (L/min) & 1.5 \\
& Plasma Gas Flow (L/min) & 15 \\
& Auxiliary Gas Flow (L/min) & 0.2 \\
\hline Selected isotopes (m/z) & $\mathrm{Se}^{82}, \mathrm{Mo}^{95}$ \\
RF power (W) & 1,500 \\
ICP-MS & Nebulizer Pump (rps) & 0.1 \\
& Plasma Gas Flow (L/min) & 15 \\
& Auxiliary Gas Flow (L/min) & 1 \\
& Carrier Gas Flow (L/min) & 0.85 \\
& Makeup Gas Flow (L/min) & 0.25 \\
\hline
\end{tabular}

\section{분석방법 검증 및 품질관리}

본 연구에서 도출된 무기질 분석법의 검증을 위해 직선 성(Linearity), 정확성(Accuracy), 정밀성(Precision)을 확인 하였다. 직선성은 무기성분 각각의 표준용액을 다량무기질 $(\mathrm{Ca}, \mathrm{P}, \mathrm{K}, \mathrm{Na}, \mathrm{Mg})$ 의 혼합표준용액은 $1-100 \mu \mathrm{g} / \mathrm{mL}$, 미량무 기질 $(\mathrm{Fe}, \mathrm{Zn}, \mathrm{Cu}, \mathrm{Mn})$ 의 혼합표준용액은 $0.01-10 \mu \mathrm{g} / \mathrm{mL}$, 초미량무기질 $(\mathrm{Se}, \mathrm{Mo})$ 의 혼합표준용액은 $1-100 \mathrm{ng} / \mathrm{mL}$ 의 농도범위에서 검량선을 작성하여 상관계수 $(\mathrm{R} 2>0.99)$ 를 확 인하였다.

정확성과 정밀성은 $\mathrm{NIST}$ 의 표준인증물질인 $\mathrm{SRM}$ 3252(Protein drink mix)를 3회 분석하여 회수율(Recovery) 및 상대표준편차(Relative standard deviation, RSD)로 확인
하였고, $\mathrm{AOAC}$ 및 Codex 가이드라인을 참고하여 유효성을 검증하였다 $(19,20)$.

또한 인증값을 알고 있는 SRM 1849a(Milk-based Infant/Adult nutritional formula I )을 내부품질관리(In house control) 시료로 선택하고, 앞서 유효성을 확립한 방법에 따라 분석 배치마다 측정하여 산출된 값을 통계적 평가에 의해 허용한계 $95 \%$ 수준 $(2 * \mathrm{SD})$ 에서 경고한계를, 허용한계 $99.7 \%$ 수준 $(3 * \mathrm{SD})$ 에서 조절한계를 설정하여 $\mathrm{QC}$ chart를 작성하고 모니터링하면서 분석 데이터의 품질관리를 하였 다.

\section{통계분석}

본 연구의 분석 결과는 모두 3 회 반복 측정한 것으로 XLSTAT-Base program(Ver. Perpetual, Addinsoft Inc., NY, USA)을 이용하여 통계처리 하였다. 과채류 품종별 무기질 함량의 평균 비교는 one-way ANOVA(Analysis of variance) test를 실시하여 분산분석 후 $95 \%$ 유의수준 $(\mathrm{p}<0.05)$ 에서 던칸 다중위검정법(Duncan's multiple range test)으로 각 실 험군 평균치 간의 유의성을 검증하였고, 무기질 함량 결과 값은 평균과 표준편차(mean $\pm \mathrm{SD})$ 로 나타내었다.

\section{결과 및 고찰}

\section{분석방법 검증 및 품질관리}

다량무기질 $(\mathrm{Ca}, \mathrm{P}, \mathrm{K}, \mathrm{Na}, \mathrm{Mg})$ 의 표준용액은 $1,5,10$, $50,100 \mu \mathrm{g} / \mathrm{mL}$, 미량무기질 $(\mathrm{Fe}, \mathrm{Zn}, \mathrm{Cu}, \mathrm{Mn})$ 의 표준용액은 $0.01,0.05,0.1,0.5,1,10 \mu \mathrm{g} / \mathrm{mL}$, 초미량무기질 $(\mathrm{Se}, \mathrm{Mo})$ 의 표준용액은 $1,5,10,50,100 \mathrm{ng} / \mathrm{mL}$ 의 농도 범위에서 검량선 작성을 통해 직선성을 확인한 결과(Fig. 1), 상관계수 $\left(\mathrm{R}^{2}\right)$ 가 0.999 이상의 우수한 결과 값으로 각각 무기질 성분의 농도 에 대하여 $\mathrm{AOAC}$ 가이드라인에서 제시하는 기준 $\left(\mathrm{R}^{2}>0.99\right)$ 을 만족시켰다.

실험결과 간의 분산 정도를 판단하여 분석 값의 재현성 을 높이기 위해 측정한 정밀성은 상대표준편차(RSD)를 통 해 확인하였고, 분석 값의 신뢰도를 높이기 위해 측정한 정확성은 NIST에서 공급하는 표준인증물질에 대해 반복 분석하여 회수율을 통해 확인하였다(Table 3). 그 결과, 상 대표준편차는 0.23-4.12\%, 회수율은 86.85-99.76\%로 분석 결과에 대한 정확성과 정밀성 모두 $\mathrm{AOAC}$ 및 Codex 가이드 라인에서 제시하는 기준(분석물 $100 \mathrm{~g}$ 당 시료 기준 농도별 상대표준편차 및 회수율 범위 80-110\%)을 만족시켰다. 또 한 분석 데이터의 품질관리를 위해 분석 배치마다 측정한 내부품질관리 시료의 모든 데이터가 경고한계 $(2 * \mathrm{SD})$ 범위 내로 나타났다(data not shown).

따라서 본 연구에서 무기질 분석에 사용한 분석법은 국 제적인 가이드라인을 충족하는 방법이었고, 이 방법을 통 
해 신뢰성이 높은 결과가 도출될 수 있었다.

\section{과일류의 품종별 무기질 함량}

무기질 함량을 분석한 과일류는 딸기는 4가지 품종(금실, 장희, 샤롯데, 죽향), 복숭아는 10 가지 품종(미황, 금황, 엘바 트, 장호원황도, 장택백봉, 미백, 천중도, 천홍, 선프레, 환타 지아), 포도는 9 가지 품종(옥랑, 청포랑, 자랑, 충랑, 자옥, 스위트드림, 천향, 샤인머스캣, $\mathrm{MBA})$, 사과는 5 가지 품종 (썸머킹, 쓰가루, 자홍, 아리수, 홍로)이었고, 그 결과를 다량 무기질은 Table 4와 6, 미량무기질은 Table 5와 7에 나타내 었다. 특히, 과일류의 무기질은 칼륨 > 인 > 칼슘 > 마그네슘 순으로 높은 함량을 보였다.

\section{딸기}

딸기의 다량무기질 평균값은 칼슘 $19.23 \mathrm{mg} / 100 \mathrm{~g}$, 인 $34.72 \mathrm{mg} / 100 \mathrm{~g}$, 나트륨 $3.15 \mathrm{mg} / 100 \mathrm{~g}$, 칼륨 $218.07 \mathrm{mg} / 100$ $\mathrm{g}$, 마그네슘 $13.49 \mathrm{mg} / 100 \mathrm{~g}$ 이었고, 미량무기질 평균값은 철 $0.46 \mathrm{mg} / 100 \mathrm{~g}$, 망간 $0.39 \mathrm{mg} / 100 \mathrm{~g}$, 아연 $0.27 \mathrm{mg} / 100$ $\mathrm{g}$, 구리 $0.03 \mathrm{mg} / 100 \mathrm{~g}$, 몰리브덴 $6.09 \mu \mathrm{g} / 100 \mathrm{~g}$, 셀레늄 $0.39 \mathrm{\mu g} / 100 \mathrm{~g}$ 이었다. 평균값과 가장 비슷한 값을 보인 품종 은 일본 품종인 장희 품종이었고, 나트륨을 제외한 모든 무기성분의 함량은 새로 육성된 국내 신품종인 금실 품종에 서 최고값을 나타냈다. 금실 품종은 칼슘 $(23.52 \mathrm{mg} / 100 \mathrm{~g})$, 인 $(45.29 \mathrm{mg} / 100 \mathrm{~g})$, 마그네슘 $(20.05 \mathrm{mg} / 100 \mathrm{~g})$, 철 $(0.87$ $\mathrm{mg} / 100 \mathrm{~g})$, 망간 $(0.58 \mathrm{mg} / 100 \mathrm{~g})$, 몰리브덴 $(8.44 \mu \mathrm{g} / 100 \mathrm{~g})$ 성분에서 과일류 중 가장 높은 값을 나타냈으며, 특히 본 연구에서 분석한 과채류 중 가장 높은 함량을 보인 칼슘과 망간은 1 일 영양섭취량 $(700 \mathrm{mg} / 100 \mathrm{~g}, 3.0 \mathrm{mg} / 100 \mathrm{~g})$ 의 $30 \%$, $19.5 \%$ 를 공급할 수 있을 것으로 생각된다. 또한 금실 품종 은 국가표준식품성분표(제9개정판)(6)에 나온 개량종과 비
교 시 1.5-3.4배 높은 함량을 나타낸 것을 알 수 있었으며, 재배적인 측면에서도 수정이 잘되고 기형과가 적어 상품과 율이 높으며 수확시기가 빠르고 저장성이 높아 수출유망 품종으로 평가 받고 있다(21). 한편 여름딸기인 샤롯데 품종 은 칼슘과 망간을 제외한 모든 무기성분 함량이 최저값을 나타내었다.

\section{복숭아}

복숭아의 다량무기질 평균값은 칼슘 $5.05 \mathrm{mg} / 100 \mathrm{~g}$, 인 $19.12 \mathrm{mg} / 100 \mathrm{~g}$, 나트륨 $2.08 \mathrm{mg} / 100 \mathrm{~g}$, 칼륨 $226.03 \mathrm{mg} / 100$ $\mathrm{g}$, 마그네슘 $4.46 \mathrm{mg} / 100 \mathrm{~g}$ 이었고, 미량무기질 평균값은 철 $0.24 \mathrm{mg} / 100 \mathrm{~g}$, 망간 $0.01 \mathrm{mg} / 100 \mathrm{~g}$, 아연 $0.26 \mathrm{mg} / 100$ $\mathrm{g}$, 구리 $0.05 \mathrm{mg} / 100 \mathrm{~g}$, 몰리브덴 $0.82 \mu \mathrm{g} / 100 \mathrm{~g}$, 셀레늄 $0.28 \mathrm{\mu g} / 100 \mathrm{~g}$ 이었다. 또한 무기성분별 유의적으로 가장 높은 품종을 보면, 칼슘은 환타지아 $(12.36 \mathrm{mg} / 100 \mathrm{~g})$, 인은 장호원황도(22.18 mg/100 g), 천중도(21.86 mg/100 g), 선프 레 $(21.64 \mathrm{mg} / 100 \mathrm{~g})$, 나트륨은 미황 $(3.07 \mathrm{mg} / 100 \mathrm{~g})$ 과 천홍 $(3.05 \mathrm{mg} / 100 \mathrm{~g})$, 칼륨은 천중도 $(271.70 \mathrm{mg} / 100 \mathrm{~g})$, 마그네슘 은 선프레 $(6.35 \mathrm{mg} / 100 \mathrm{~g})$, 철, 망간, 구리는 미황(각각 0.35 $\mathrm{mg} / 100 \mathrm{~g}, 0.02 \mathrm{mg} / 100 \mathrm{~g}, 0.10 \mathrm{mg} / 100 \mathrm{~g})$, 아연은 금황( 0.62 $\mathrm{mg} / 100 \mathrm{~g})$, 몰리브덴은 금황 $(1.98 \mu \mathrm{gg} / 100 \mathrm{~g})$ 과 장호원황도 $(2.01 \mu \mathrm{g} / 100 \mathrm{~g})$, 셀레늄은 엘바트 $(1.71 \mu \mathrm{g} / 100 \mathrm{~g})$ 이었고, 그 중 칼슘, 몰리브덴, 셀레늄은 평균값과 $2.4,2.5,6.2$ 배의 큰 차이로 높은 값을 나타냈다. 특히 다량무기질 함량이 높은 품종은 천도 품종(천홍, 선프레, 환타지아)과 백도(천 중도, 장택백봉, 미백) 중 천중도 품종이었으며, 미량무기질 함량은 황도 품종(금황, 미황, 엘바트, 장호원황도)에서 높 은 값을 나타내었다.

Table 3. Relative standard deviation and recovery of SRM 3252

\begin{tabular}{ccccc}
\hline Compound & Analyzed value & Reference value $)^{1)}$ & Recovery $(\%)^{2)}$ & RSD (\% $)^{3)}$ \\
\hline $\mathrm{Ca}(\mathrm{mg} / 100 \mathrm{~g})$ & $1683.90 \pm 5.72$ & $1784.0 \pm 99.00$ & 94.39 & 0.34 \\
$\mathrm{P}(\mathrm{mg} / 100 \mathrm{~g})$ & $1494.65 \pm 31.04$ & $1721.0 \pm 70.00$ & 86.85 & 2.08 \\
$\mathrm{~K}(\mathrm{mg} / 100 \mathrm{~g})$ & $1062.63 \pm 20.32$ & $1155.0 \pm 53.00$ & 92.00 & 1.91 \\
$\mathrm{Na}(\mathrm{mg} / 100 \mathrm{~g})$ & $680.38 \pm 1.56$ & $682.0 \pm 17.00$ & 99.76 & 0.23 \\
$\mathrm{Mg}(\mathrm{mg} / 100 \mathrm{~g})$ & $604.78 \pm 4.99$ & $633.7 \pm 17.40$ & 95.44 & 0.82 \\
$\mathrm{Fe}(\mathrm{mg} / 100 \mathrm{~g})$ & $34.64 \pm 0.25$ & $38.1 \pm 1.30$ & 90.91 & 0.72 \\
$\mathrm{Mn}(\mathrm{mg} / 100 \mathrm{~g})$ & $1.07 \pm 0.01$ & $1.1 \pm 0.05$ & 96.39 & 0.84 \\
$\mathrm{Zn}(\mathrm{mg} / 100 \mathrm{~g})$ & $20.43 \pm 0.11$ & $23.5 \pm 1.20$ & 86.95 & 0.52 \\
$\mathrm{Cu}(\mathrm{mg} / 100 \mathrm{~g})$ & $3.27 \pm 0.08$ & $3.6 \pm 0.07$ & 90.00 & 2.46 \\
$\mathrm{Mo}(\mu \mathrm{g} / 100 \mathrm{~g})$ & $107.48 \pm 2.11$ & $119.0 \pm 20.00$ & 90.32 & 1.97 \\
$\mathrm{Se}(\mu \mathrm{g} / 100 \mathrm{~g})$ & $58.06 \pm 2.39$ & $59.6 \pm 3.70$ & 97.41 & 4.12
\end{tabular}

\footnotetext{
${ }^{1)}$ Values are means \pm standard deviation.

${ }^{2)}$ Recovery $(\%)=$ analysis value/reference value $\times 100$

${ }^{3)}$ Relative standard deviation.
} 
Table 4. Comparison of macro mineral contents of strawberries, peaches and grape varieties

\begin{tabular}{|c|c|c|c|c|c|c|}
\hline Sample & Varieties & $\begin{array}{c}\mathrm{Ca} \\
(\mathrm{mg} / 100 \mathrm{~g})\end{array}$ & $\begin{array}{c}\mathrm{P} \\
(\mathrm{mg} / 100 \mathrm{~g})\end{array}$ & $\begin{array}{c}\mathrm{Na} \\
(\mathrm{mg} / 100 \mathrm{~g})\end{array}$ & $\begin{array}{c}\mathrm{K} \\
(\mathrm{mg} / 100 \mathrm{~g})\end{array}$ & $\begin{array}{c}\mathrm{Mg} \\
(\mathrm{mg} / 100 \mathrm{~g})\end{array}$ \\
\hline \multirow{4}{*}{ Strawberries } & Geumsil & $23.52 \pm 0.28^{\mathrm{al})}$ & $45.29 \pm 0.55^{\mathrm{a}}$ & $3.43 \pm 0.16^{\mathrm{b}}$ & $255.21 \pm 4.16^{\mathrm{a}}$ & $20.05 \pm 0.21^{\mathrm{a}}$ \\
\hline & Janghee & $19.38 \pm 0.15^{\mathfrak{c}}$ & $36.47 \pm 0.49^{b}$ & $4.83 \pm 0.06^{\mathrm{a}}$ & $228.25 \pm 2.55^{b}$ & $13.99 \pm 0.12^{b}$ \\
\hline & Charlotte & $20.04 \pm 0.22^{\mathrm{b}}$ & $25.80 \pm 0.26^{\mathrm{d}}$ & $2.47 \pm 0.03^{\mathrm{c}}$ & $168.74 \pm 2.18^{d}$ & $9.42 \pm 0.10^{d}$ \\
\hline & Jukhyang & $13.98 \pm 0.08^{\mathrm{d}}$ & $31.32 \pm 0.19^{c}$ & $1.87 \pm 0.04^{\mathrm{d}}$ & $220.09 \pm 1.90^{c}$ & $10.50 \pm 0.07^{\mathrm{c}}$ \\
\hline \multirow{10}{*}{ Peach } & Mihwang & $4.99 \pm 0.05^{\mathrm{d}}$ & $19.78 \pm 0.14^{\mathrm{b}}$ & $3.07 \pm 0.03^{\mathrm{a}}$ & $210.11 \pm 1.15^{\mathrm{e}}$ & $5.18 \pm 0.11^{\mathrm{c}}$ \\
\hline & Geumhwang & $5.82 \pm 0.11^{\mathrm{c}}$ & $15.66 \pm 0.34^{\mathrm{f}}$ & $1.70 \pm 0.05^{\mathrm{f}}$ & $199.40 \pm 2.66^{\mathrm{f}}$ & $4.44 \pm 0.11^{\mathrm{d}}$ \\
\hline & Elbat & $3.11 \pm 0.08^{f}$ & $18.06 \pm 0.16^{\mathrm{cd}}$ & $0.72 \pm 0.01^{\mathrm{h}}$ & $209.97 \pm 0.61^{\mathrm{e}}$ & $2.93 \pm 0.09^{\mathrm{fg}}$ \\
\hline & Changhowon Hwangdo & $3.25 \pm 0.10^{f}$ & $22.18 \pm 0.57^{\mathrm{a}}$ & $1.48 \pm 0.03^{\mathrm{g}}$ & $245.86 \pm 7.17^{b}$ & $3.89 \pm 0.19^{f}$ \\
\hline & Nagasawa Hakuho & $2.64 \pm 0.05^{\mathrm{g}}$ & $19.34 \pm 0.05^{b}$ & $1.86 \pm 0.02^{\mathrm{e}}$ & $233.24 \pm 2.08^{c}$ & $3.93 \pm 0.05^{\mathrm{e}}$ \\
\hline & Mibaek & $3.14 \pm 0.09^{f}$ & $16.51 \pm 0.30^{e}$ & $2.18 \pm 0.02^{\mathrm{d}}$ & $233.21 \pm 0.86^{\mathrm{C}}$ & $2.87 \pm 0.11^{\mathrm{g}}$ \\
\hline & CheonJungdo & $2.74 \pm 0.02^{\mathrm{g}}$ & $21.86 \pm 0.03^{\mathrm{a}}$ & $1.41 \pm 0.02^{\mathrm{g}}$ & $271.70 \pm 3.72^{\mathrm{a}}$ & $4.10 \pm 0.02^{\mathrm{e}}$ \\
\hline & Cheonhong & $8.18 \pm 0.15^{b}$ & $18.41 \pm 0.40^{c}$ & $3.05 \pm 0.13^{\mathrm{a}}$ & $204.34 \pm 0.98^{\mathrm{f}}$ & $4.98 \pm 0.15^{\mathrm{c}}$ \\
\hline & Sunfre & $4.30 \pm 0.10^{\mathrm{e}}$ & $21.64 \pm 0.41^{\mathrm{a}}$ & $2.53 \pm 0.11^{\mathrm{c}}$ & $228.90 \pm 2.85^{\mathrm{c}}$ & $6.35 \pm 0.19^{\mathrm{a}}$ \\
\hline & Fantasia & $12.36 \pm 0.12^{\mathrm{a}}$ & $17.79 \pm 0.17^{\mathrm{d}}$ & $2.77 \pm 0.06^{b}$ & $223.55 \pm 1.04^{\mathrm{d}}$ & $5.94 \pm 0.06^{\mathrm{b}}$ \\
\hline \multirow{9}{*}{ Grape } & Okrang & $6.75 \pm 0.08^{d}$ & $13.46 \pm 0.19^{f}$ & $3.12 \pm 0.10^{b}$ & $215.91 \pm 2.77^{c}$ & $1.28 \pm 0.04^{\mathrm{h}}$ \\
\hline & Jarang & $6.68 \pm 0.18^{d}$ & $18.90 \pm 0.32^{\mathrm{b}}$ & $1.00 \pm 0.04^{\mathrm{f}}$ & $170.42 \pm 2.97^{\circ}$ & $2.93 \pm 0.13^{\mathrm{f}}$ \\
\hline & Chungrang & $4.99 \pm 0.02^{\mathrm{g}}$ & $16.18 \pm 0.17^{c}$ & $1.06 \pm 0.05^{\mathrm{f}}$ & $151.06 \pm 1.26^{\mathrm{f}}$ & $3.45 \pm 0.02^{\mathrm{e}}$ \\
\hline & Jaok & $10.43 \pm 0.17^{b}$ & $22.36 \pm 0.27^{\mathrm{a}}$ & $1.59 \pm 0.02^{\mathrm{e}}$ & $232.18 \pm 1.43^{b}$ & $8.22 \pm 0.12^{\mathrm{a}}$ \\
\hline & Sweetdream & $9.34 \pm 0.29^{c}$ & $15.50 \pm 0.26^{\mathrm{d}}$ & $1.90 \pm 0.01^{\mathrm{d}}$ & $149.59 \pm 2.08^{\mathrm{f}}$ & $4.56 \pm 0.20^{c}$ \\
\hline & Cheongporang & $5.27 \pm 0.06^{\mathrm{f}}$ & $13.89 \pm 0.13^{\mathrm{f}}$ & $3.30 \pm 0.03^{\mathrm{a}}$ & $144.56 \pm 3.11^{\mathrm{g}}$ & $3.84 \pm 0.05^{\mathrm{d}}$ \\
\hline & Cheonghyang & $6.85 \pm 0.18^{d}$ & $12.23 \pm 0.36^{\mathrm{g}}$ & $0.68 \pm 0.01^{\mathrm{g}}$ & $172.23 \pm 3.56^{\mathrm{e}}$ & $3.34 \pm 0.12^{\mathrm{e}}$ \\
\hline & Shine Muskat & $12.28 \pm 0.16^{\mathrm{a}}$ & $19.29 \pm 0.33^{b}$ & $1.05 \pm 0.01^{\mathrm{f}}$ & $241.42 \pm 3.67^{\mathrm{a}}$ & $4.86 \pm 0.08^{b}$ \\
\hline & Muscat Baily A (MBA) & $6.27 \pm 0.13^{\mathrm{e}}$ & $14.24 \pm 0.30^{e}$ & $2.34 \pm 0.06^{c}$ & $190.94 \pm 0.63^{\mathrm{d}}$ & $1.47 \pm 0.07^{g}$ \\
\hline
\end{tabular}

\footnotetext{
${ }^{11}$ All values are expressed as mean \pm SD of triplicate determinations. Means with different superscripts within a each column (a-h) are significantly different at $p<0.05$ by
} Duncan's multiple range test.

\section{포도}

포도의 다량무기질 평균값은 칼슘 $7.65 \mathrm{mg} / 100 \mathrm{~g}$, 인 $16.23 \mathrm{mg} / 100 \mathrm{~g}$, 나트륨 $1.78 \mathrm{mg} / 100 \mathrm{~g}$, 칼륨 $185.37 \mathrm{mg} / 100$ $\mathrm{g}$, 마그네슘 $3.77 \mathrm{mg} / 100 \mathrm{~g}$ 이었고, 미량무기질 평균값은 철 $0.25 \mathrm{mg} / 100 \mathrm{~g}$, 망간 $0.05 \mathrm{mg} / 100 \mathrm{~g}$, 아연 $0.13 \mathrm{mg} / 100$ $\mathrm{g}$, 구리 $0.06 \mathrm{mg} / 100 \mathrm{~g}$, 몰리브덴 $0.67 \mu \mathrm{g} / 100 \mathrm{~g}$, 셀레늄 $0.76 \mu \mathrm{g} / 100 \mathrm{~g}$ 이었다. 또한 무기성분별 유의적으로 가장 높은 품종을 보면, 칼슘과 칼륨은 샤인머스켓(각각 12.28 $\mathrm{mg} / 100 \mathrm{~g}, 241.42 \mathrm{mg} / 100 \mathrm{~g}$ ), 인, 마그네슘 및 셀레늄은 자옥 (각각 $22.36 \mathrm{mg} / 100 \mathrm{~g}, 8.22 \mathrm{mg} / 100 \mathrm{~g}, 1.88 \mu \mathrm{g} / 100 \mathrm{~g}$ ), 나트륨 은 청포랑 $(3.30 \mathrm{mg} / 100 \mathrm{~g})$, 철은 $\mathrm{MBA}(0.69 \mathrm{mg} / 100 \mathrm{~g})$, 망간 은 청향 $(0.27 \mathrm{mg} / 100 \mathrm{~g})$, 아연은 스위트드림 $(0.30 \mathrm{mg} / 100$ $\mathrm{g})$ 과 $\mathrm{MBA}(0.40 \mathrm{mg} / 100 \mathrm{~g})$, 구리는 자랑과 $\mathrm{MBA}(0.08$ $\mathrm{mg} / 100 \mathrm{~g})$, 몰리브덴은 스위트드림 $(2.13 \mu \mathrm{g} 100 \mathrm{~g})$ 이었고, 그 중 마그네슘과 미량무기질은 평균값과 2.2-5.1배의 큰 차이로 높은 값을 보였다. 특히 적포도 품종(옥랑, 자랑, 충랑, 스위트드림, $\mathrm{MBA}$ )와 백포도 품종(청포랑, 청향, 샤인
머스켓)의 무기성분간 특이적인 상관관계가 없는 것으로 나타났는데, 이는 자랑과 샤인머스켓을 제외하고 껍질이 포함되지 않은 가식부 형태로 분석하였기 때문으로 사료된 다. 흑색의 자옥과 청색의 샤인머스켓 품종은 다량무기질 $(\mathrm{Ca}, \mathrm{P}, \mathrm{K}, \mathrm{Mg})$ 에서 높은 함량을 나타냈으며, 그 중 칼슘과 칼륨에서 가장 높은 값을 나타낸 샤인머스켓 품종은 국가표 준식품성분표(제9개정판)(6)에 나온 동일 품종(샤인머스 켓, 껍질 포함)과 비교 시 1.1-1.8배의 더 높은 값을 보였고, 이는 동일 품종이지만 생산지와 생산시기에 따라 성분값이 차이를 나타낸다는 것을 보여주는 것으로 사료된다.

포도의 주요 가공품인 포도주는 포도의 품종이 그 품질 을 결정하는 가장 중요한 요소로, 포도주의 탁도와 관련된 bitartrate를 생성하는 칼륨과 칼슘 함량이 가장 낮고, 양조 시 살균 및 산화 방지 역할을 하는 나트륨 함량이 높은 품종이 좋다(21). 이에 본 연구에서 분석한 청포랑 품종이 포도주 제조에 좋은 품종이라고 판단되며, 재배적인 측면 에서도 착립률과 착과량이 높은 다수성 품종으로 화이트와 
인 등 주스용으로 이용하기 좋은 품종으로 평가받고 있다 (23).

사과

사과의 다량무기질 평균값은 칼슘 $3.49 \mathrm{mg} / 100 \mathrm{~g}$, 인 $11.28 \mathrm{mg} / 100 \mathrm{~g}$, 나트륨 $2.12 \mathrm{mg} / 100 \mathrm{~g}$, 칼륨 $146.61 \mathrm{mg} / 100$ $\mathrm{g}$, 마그네슘 $2.20 \mathrm{mg} / 100 \mathrm{~g}$ 이었고, 미량무기질 평균값은 철 $0.31 \mathrm{mg} / 100 \mathrm{~g}$, 망간 $0.01 \mathrm{mg} / 100 \mathrm{~g}$, 아연 $0.07 \mathrm{mg} / 100$ $\mathrm{g}$, 구리 $0.02 \mathrm{mg} / 100 \mathrm{~g}$, 몰리브덴 $1.69 \mathrm{\mu g} / 100 \mathrm{~g}$, 셀레늄 $0.67 \mathrm{\mu g} / 100 \mathrm{~g}$ 이었다. 또한 무기성분별 유의적으로 가장 높은 품종을 보면, 칼슘과 마그네슘은 아리수(각각 6.04 $\mathrm{mg} / 100 \mathrm{~g}, 2.55 \mathrm{mg} / 100 \mathrm{~g}$ ), 인과 칼륨, 셀레늄은 자홍(각각 $13.12 \mathrm{mg} / 100 \mathrm{~g}, 181.14 \mathrm{mg} / 100 \mathrm{~g}, 2.16 \mu \mathrm{g} / 100 \mathrm{~g}$ ), 나트륨, 아연은 홍로(각각 $3.07 \mathrm{mg} / 100 \mathrm{~g}, 0.12 \mathrm{mg} / 100 \mathrm{~g}$ ), 철은 썸머 킹 $(0.72 \mathrm{mg} / 100 \mathrm{~g})$, 망간과 구리, 몰리브덴은 쓰가루(각각 $0.018 \mathrm{mg} / 100 \mathrm{~g}, 0.03 \mathrm{mg} / 100 \mathrm{~g}, 2.78 \mu \mathrm{g} / 100 \mathrm{~g}$ )이었고, 그
중 철과 셀레늄은 평균값과 $2.3,3.2$ 배의 큰 차이로 높은 값을 나타내었다. 셀레늄은 자홍 품종이 본 연구에서 분석 한 과채류 중 가장 높은 함량으로 1 일 영양섭취량 $(55 \mathrm{\mu g} / 100$ $\mathrm{g})$ 의 $3.9 \%$ 를 공급할 수 있을 것으로 생각된다. 특히 자색을 갖는 가을사과인 자홍, 아리수, 홍로 품종에서 다량무기질 함량이 높았으며, 청색을 갖는 여름사과인 썸머킹, 쓰가루 (아오리) 품종에서는 미량 무기질 함량이 높게 측정되었고, 그 중 아오리 품종의 경우 국가표준식품성분표(제9개정 판)(6)에 나온 동일 품종(아오리, 껍질 포함)과 비교 시 철, 아연, 몰리브덴 값이 $2.6,3.5,4.3$ 배 높게 측정되어 이 또한 품종은 동일하지만 생산지와 생산시기에 따라 성분 값이 차이를 나타낸다는 것을 보여주고 있다.

동일한 품종에서 생산지에 따른 차이를 확인하기 위해 사과의 홍로 품종을 8 개 지역에서 재배한 값을 비교하였고, 그 결과를 다량무기질은 Table 6, 미량무기질은 Table 7에 나타내었다. 각 무기성분은 산지별로 시료 간 유의적인 차

Table 5. Comparison of micro mineral contents of strawberries, peaches and grape varieties

\begin{tabular}{|c|c|c|c|c|c|c|c|}
\hline Sample & Varieties & $\begin{array}{c}\mathrm{Fe} \\
(\mathrm{mg} / 100 \mathrm{~g})\end{array}$ & $\begin{array}{c}\mathrm{Mn} \\
(\mathrm{mg} / 100 \mathrm{~g})\end{array}$ & $\begin{array}{c}\mathrm{Zn} \\
(\mathrm{mg} / 100 \mathrm{~g})\end{array}$ & $\begin{array}{c}\mathrm{Cu} \\
(\mathrm{mg} / 100 \mathrm{~g})\end{array}$ & $\begin{array}{c}\text { Mo } \\
(\mu \mathrm{g} / 100 \mathrm{~g})\end{array}$ & $\begin{array}{c}\mathrm{Se} \\
(\mu \mathrm{g} / 100 \mathrm{~g})\end{array}$ \\
\hline \multirow{4}{*}{ Strawberries } & Geumsil & $0.87 \pm 0.00^{\mathrm{al})}$ & $0.584 \pm 0.02 \mathrm{a}$ & $0.33 \pm 0.00 \mathrm{a}$ & $0.06 \pm 0.00 \mathrm{a}$ & $8.44 \pm 0.65^{\mathrm{a}}$ & $\mathrm{ND}^{2)}$ \\
\hline & Janghee & $0.35 \pm 0.00^{c}$ & $0.308 \pm 0.01 \mathrm{c}$ & $0.23 \pm 0.00 c$ & $0.04 \pm 0.00 \mathrm{~b}$ & $6.00 \pm 0.06^{b}$ & $\mathrm{ND}$ \\
\hline & Charlotte & $0.25 \pm 0.00^{d}$ & $0.514 \pm 0.00 \mathrm{~b}$ & $0.22 \pm 0.00 \mathrm{~d}$ & $\mathrm{ND}$ & $4.09 \pm 0.12^{\mathrm{c}}$ & $0.76 \pm 0.10^{\mathrm{a}}$ \\
\hline & Jukhyang & $0.39 \pm 0.01^{b}$ & $0.159 \pm 0.00 \mathrm{~d}$ & $0.30 \pm 0.00 \mathrm{~b}$ & $0.04 \pm 0.00 \mathrm{~b}$ & $5.81 \pm 0.14^{\mathrm{b}}$ & $0.81 \pm 0.08^{\mathrm{a}}$ \\
\hline \multirow{10}{*}{ Peach } & Mihwang & $0.35 \pm 0.00^{\mathrm{a}}$ & $0.024 \pm 0.00 \mathrm{a}$ & $0.18 \pm 0.00 \mathrm{e}$ & $0.10 \pm 0.01 \mathrm{a}$ & $\mathrm{ND}$ & $\mathrm{ND}$ \\
\hline & Geumhwang & $0.28 \pm 0.02^{c}$ & $0.009 \pm 0.00 \mathrm{~d}$ & $0.62 \pm 0.02 \mathrm{a}$ & $0.05 \pm 0.00 c$ & $1.98 \pm 0.13^{\mathrm{a}}$ & ND \\
\hline & Elbat & $0.19 \pm 0.00^{f}$ & $0.007 \pm 0.00 \mathrm{e}$ & $0.14 \pm 0.00 \mathrm{f}$ & $0.05 \pm 0.00 \mathrm{~d}$ & $0.67 \pm 0.08^{d}$ & $1.71 \pm 0.06^{\mathrm{a}}$ \\
\hline & Changhowon Hwangdo & $0.31 \pm 0.00^{b}$ & $\mathrm{ND}$ & $0.15 \pm 0.00 \mathrm{f}$ & $0.04 \pm 0.00 \mathrm{e}$ & $2.01 \pm 0.28^{\mathrm{a}}$ & $1.06 \pm 0.10^{b}$ \\
\hline & Nagasawa Hakuho & $0.18 \pm 0.00^{f}$ & $\mathrm{ND}$ & $0.23 \pm 0.00 \mathrm{~d}$ & $0.05 \pm 0.00 \mathrm{~cd}$ & $0.89 \pm 0.09^{c}$ & $\mathrm{ND}$ \\
\hline & Mibaek & $0.13 \pm 0.00^{\mathrm{g}}$ & $\mathrm{ND}$ & $0.11 \pm 0.00 \mathrm{~g}$ & $0.04 \pm 0.00 \mathrm{e}$ & $0.14 \pm 0.02^{\mathrm{f}}$ & $\mathrm{ND}$ \\
\hline & CheonJungdo & $0.21 \pm 0.00^{\mathrm{e}}$ & $\mathrm{ND}$ & $0.18 \pm 0.00 \mathrm{e}$ & $0.05 \pm 0.00 \mathrm{~cd}$ & $0.45 \pm 0.08^{\mathrm{e}}$ & $\mathrm{ND}$ \\
\hline & Cheonhong & $0.26 \pm 0.00^{\mathrm{d}}$ & $0.018 \pm 0.00 \mathrm{~b}$ & $0.54 \pm 0.01 \mathrm{~b}$ & $0.05 \pm 0.00 \mathrm{~d}$ & $0.49 \pm 0.02^{\mathrm{de}}$ & $\mathrm{ND}$ \\
\hline & Sunfre & $0.21 \pm 0.00^{\mathrm{e}}$ & $0.019 \pm 0.00 \mathrm{~b}$ & $0.33 \pm 0.03 c$ & $0.03 \pm 0.00 \mathrm{f}$ & $1.48 \pm 0.08^{b}$ & $\mathrm{ND}$ \\
\hline & Fantasia & $0.32 \pm 0.00^{b}$ & $0.016 \pm 0.00 \mathrm{c}$ & $0.14 \pm 0.00 \mathrm{f}$ & $0.08 \pm 0.00 \mathrm{~b}$ & $0.06 \pm 0.00^{f}$ & $\mathrm{ND}$ \\
\hline \multirow{9}{*}{ Grape } & Okrang & $0.26 \pm 0.00^{b}$ & $0.015 \pm 0.00 \mathrm{~d}$ & $0.15 \pm 0.00^{b}$ & $0.01 \pm 0.00^{f}$ & $\mathrm{ND}$ & $\mathrm{ND}$ \\
\hline & Jarang & $0.17 \pm 0.00^{\mathrm{e}}$ & ND & $0.03 \pm 0.00^{\mathrm{b}}$ & $0.08 \pm 0.00^{\mathrm{a}}$ & $0.67 \pm 0.06^{c}$ & $0.54 \pm 0.05^{\mathrm{e}}$ \\
\hline & Chungrang & $0.13 \pm 0.00^{g}$ & $0.016 \pm 0.00^{\mathrm{d}}$ & $0.09 \pm 0.00^{\mathrm{b}}$ & $0.04 \pm 0.00^{d}$ & $0.39 \pm 0.01^{\mathrm{d}}$ & $1.16 \pm 0.13^{\mathrm{c}}$ \\
\hline & Jaok & $0.17 \pm 0.00^{\mathrm{ef}}$ & $0.034 \pm 0.01^{\mathrm{c}}$ & $0.05 \pm 0.00^{\mathrm{b}}$ & $0.06 \pm 0.00^{c}$ & $0.32 \pm 0.04^{d}$ & $1.88 \pm 0.12^{\mathrm{a}}$ \\
\hline & Sweetdream & $0.17 \pm 0.00^{f}$ & $0.034 \pm 0.00^{c}$ & $0.30 \pm 0.00^{\mathrm{a}}$ & $0.07 \pm 0.00^{\mathrm{b}}$ & $2.13 \pm 0.13^{\mathrm{a}}$ & $0.74 \pm 0.06^{\mathrm{d}}$ \\
\hline & Cheongporang & $0.25 \pm 0.00^{b}$ & $0.076 \pm 0.00^{b}$ & $0.10 \pm 0.00^{\mathrm{b}}$ & $0.03 \pm 0.00^{\mathrm{e}}$ & $\mathrm{ND}$ & $\mathrm{ND}$ \\
\hline & Cheonghyang & $0.18 \pm 0.00^{\mathrm{d}}$ & $0.270 \pm 0.00^{\mathrm{a}}$ & $0.05 \pm 0.00^{b}$ & $0.08 \pm 0.00^{\mathrm{a}}$ & $0.42 \pm 0.00^{d}$ & $0.63 \pm 0.10^{\text {de }}$ \\
\hline & Shine Muskat & $0.22 \pm 0.00^{c}$ & $0.005 \pm 0.00^{\mathrm{d}}$ & $0.04 \pm 0.00^{\mathrm{b}}$ & $0.07 \pm 0.00^{b}$ & $1.95 \pm 0.09^{b}$ & $1.38 \pm 0.08^{\mathrm{b}}$ \\
\hline & Muscat Baily A (MBA) & $0.69 \pm 0.00^{\mathrm{a}}$ & $\mathrm{ND}$ & $0.40 \pm 0.00^{\mathrm{a}}$ & $0.08 \pm 0.01^{\mathrm{a}}$ & $0.10 \pm 0.01^{\mathrm{e}}$ & $0.49 \pm 0.03^{\mathrm{e}}$ \\
\hline
\end{tabular}

\footnotetext{
${ }^{1)}$ All values are expressed as mean \pm SD of triplicate determinations. Means with different superscripts within a column (a-g) are significantly different at $\mathrm{p}<0.05$ by Duncan's multiple range test.

${ }^{2}$ Not detected.
} 
Table 6. Comparison of macro mineral contents of apple varieties and apple Hongro varieties by regions

\begin{tabular}{|c|c|c|c|c|c|c|}
\hline Sample & Varieties & $\begin{array}{c}\mathrm{Ca} \\
(\mathrm{mg} / 100 \mathrm{~g})\end{array}$ & $\begin{array}{c}\mathrm{P} \\
(\mathrm{mg} / 100 \mathrm{~g})\end{array}$ & $\begin{array}{c}\mathrm{Na} \\
(\mathrm{mg} / 100 \mathrm{~g})\end{array}$ & $\begin{array}{c}\mathrm{K} \\
(\mathrm{mg} / 100 \mathrm{~g})\end{array}$ & $\begin{array}{c}\mathrm{Mg} \\
(\mathrm{mg} / 100 \mathrm{~g})\end{array}$ \\
\hline \multirow{5}{*}{ Apple } & SummerKing & $3.25 \pm 0.09^{b 1)}$ & $10.72 \pm 0.13^{\mathrm{d}}$ & $1.96 \pm 0.01^{b}$ & $164.01 \pm 0.84^{b}$ & $2.06 \pm 0.07^{\mathrm{c}}$ \\
\hline & Tsugaru & $2.45 \pm 0.06^{\mathrm{c}}$ & $9.96 \pm 0.14^{\mathrm{e}}$ & $3.08 \pm 0.10^{\mathrm{a}}$ & $131.79 \pm 1.17^{\mathrm{d}}$ & $2.36 \pm 0.06^{b}$ \\
\hline & Jahong & $3.31 \pm 0.05^{b}$ & $13.12 \pm 0.22^{\mathrm{a}}$ & $1.33 \pm 0.04^{\mathrm{c}}$ & $181.14 \pm 1.01^{\mathrm{a}}$ & $2.34 \pm 0.03^{b}$ \\
\hline & Arisoo & $6.04 \pm 0.07^{\mathrm{a}}$ & $11.59 \pm 0.10^{b}$ & $1.16 \pm 0.02^{\mathrm{d}}$ & $97.28 \pm 0.95^{\mathrm{e}}$ & $2.55 \pm 0.04^{\mathrm{a}}$ \\
\hline & Hongro & $2.42 \pm 0.06^{\mathrm{c}}$ & $11.00 \pm 0.14^{c}$ & $3.07 \pm 0.05^{\mathrm{a}}$ & $158.83 \pm 1.87^{\mathrm{c}}$ & $1.68 \pm 0.09^{\mathrm{d}}$ \\
\hline \multirow{8}{*}{$\begin{array}{c}\text { Apple } \\
\text { (Hongro var.) }\end{array}$} & Chuncheon & $2.89 \pm 0.11^{\mathrm{c}}$ & $9.13 \pm 0.16^{\mathrm{f}}$ & $3.36 \pm 0.08^{b}$ & $157.63 \pm 1.69^{c}$ & $1.83 \pm 0.14^{\mathrm{c}}$ \\
\hline & Pocheon & $2.54 \pm 0.04^{\mathrm{d}}$ & $9.57 \pm 0.20^{e}$ & $2.73 \pm 0.04^{\mathrm{ef}}$ & $141.88 \pm 2.53^{\mathrm{e}}$ & $0.98 \pm 0.04^{f}$ \\
\hline & Cheongju & $3.02 \pm 0.03^{\mathrm{b}}$ & $12.67 \pm 0.07^{\mathrm{a}}$ & $3.28 \pm 0.03^{b}$ & $159.91 \pm 2.43^{\mathrm{c}}$ & $1.78 \pm 0.26^{\mathrm{c}}$ \\
\hline & Yesan & $3.15 \pm 0.06^{\mathrm{a}}$ & $12.83 \pm 0.05^{\mathrm{a}}$ & $2.65 \pm 0.13^{\mathrm{f}}$ & $175.83 \pm 1.05^{b}$ & $2.30 \pm 0.05^{\mathrm{a}}$ \\
\hline & Jangsu & $1.28 \pm 0.05^{\mathrm{g}}$ & $10.14 \pm 0.04^{d}$ & $2.91 \pm 0.03^{\mathrm{d}}$ & $193.66 \pm 2.54^{\mathrm{a}}$ & $2.15 \pm 0.05^{b}$ \\
\hline & Jangseong & $1.55 \pm 0.05^{f}$ & $11.54 \pm 0.22^{b}$ & $3.14 \pm 0.07^{c}$ & $156.74 \pm 1.08^{c}$ & $1.30 \pm 0.04^{\mathrm{e}}$ \\
\hline & Yeongcheon & $2.63 \pm 0.07^{\mathrm{d}}$ & $10.52 \pm 0.20^{c}$ & $3.65 \pm 0.01^{\mathrm{a}}$ & $135.76 \pm 1.73^{\mathrm{f}}$ & $1.55 \pm 0.06^{\mathrm{d}}$ \\
\hline & Geochang & $2.29 \pm 0.09^{\mathrm{e}}$ & $11.57 \pm 0.21^{b}$ & $2.81 \pm 0.05^{\mathrm{de}}$ & $149.23 \pm 1.92^{\mathrm{d}}$ & $1.51 \pm 0.05^{\mathrm{d}}$ \\
\hline
\end{tabular}

${ }^{11}$ All values are expressed as mean \pm SD of triplicate determinations. Means with different superscripts within a each column (a-g) are significantly different at $\mathrm{p}<0.05$ by Duncan's multiple range test.

Table 7. Comparison of micro mineral contents of apple varieties and apple Hongro varieties by regions

\begin{tabular}{|c|c|c|c|c|c|c|c|}
\hline Sample & Varieties & $\begin{array}{c}\mathrm{Fe} \\
(\mathrm{mg} / 100 \mathrm{~g})\end{array}$ & $\begin{array}{c}\mathrm{Mn} \\
(\mathrm{mg} / 100 \mathrm{~g})\end{array}$ & $\begin{array}{c}\mathrm{Zn} \\
(\mathrm{mg} / 100 \mathrm{~g})\end{array}$ & $\begin{array}{c}\mathrm{Cu} \\
(\mathrm{mg} / 100 \mathrm{~g})\end{array}$ & $\begin{array}{c}\text { Mo } \\
(\mu \mathrm{g} / 100 \mathrm{~g}) \\
\end{array}$ & $\begin{array}{c}\mathrm{Se} \\
(\mu \mathrm{g} / 100 \mathrm{~g})\end{array}$ \\
\hline \multirow{5}{*}{ Apple } & SummerKing & $0.72 \pm 0.01^{\mathrm{al})}$ & $0.016 \pm 0.00^{b}$ & $0.06 \pm 0.00^{c}$ & $0.006 \pm 0.00^{\mathrm{d}}$ & $\mathrm{ND}^{2)}$ & $\mathrm{ND}$ \\
\hline & Tsugaru & $0.29 \pm 0.00^{b}$ & $0.018 \pm 0.00^{\mathrm{a}}$ & $0.07 \pm 0.00^{b}$ & $0.030 \pm 0.00^{\mathrm{a}}$ & $2.78 \pm 0.06^{\mathrm{a}}$ & ND \\
\hline & Jahong & $0.17 \pm 0.00^{\mathrm{d}}$ & $0.011 \pm 0.00^{c}$ & $0.04 \pm 0.00^{e}$ & $0.023 \pm 0.00^{b}$ & $1.87 \pm 0.09^{c}$ & $2.16 \pm 0.03^{\mathrm{a}}$ \\
\hline & Arisoo & $0.12 \pm 0.00^{\mathrm{e}}$ & $0.009 \pm 0.00^{d}$ & $0.05 \pm 0.00^{\mathrm{d}}$ & $0.029 \pm 0.00^{\mathrm{a}}$ & $1.68 \pm 0.07^{\mathrm{d}}$ & $1.10 \pm 0.03^{b}$ \\
\hline & Hongro & $0.25 \pm 0.00^{c}$ & $0.012 \pm 0.00^{c}$ & $0.12 \pm 0.00^{\mathrm{a}}$ & $0.018 \pm 0.00^{c}$ & $2.12 \pm 0.07^{\mathrm{b}}$ & $0.10 \pm 0.01^{c}$ \\
\hline \multirow{8}{*}{$\begin{array}{c}\text { Apple } \\
\text { (Hongro var.) }\end{array}$} & Chuncheon & $0.26 \pm 0.01^{b}$ & $0.029 \pm 0.00^{\mathrm{a}}$ & $0.15 \pm 0.00^{c}$ & $0.013 \pm 0.00^{c}$ & $2.38 \pm 0.17^{\mathrm{d}}$ & $\mathrm{ND}$ \\
\hline & Pocheon & $0.22 \pm 0.00^{c}$ & $0.015 \pm 0.00^{\mathrm{d}}$ & $0.18 \pm 0.00^{\mathrm{a}}$ & $0.007 \pm 0.00^{\mathrm{d}}$ & $1.32 \pm 0.07^{\mathrm{f}}$ & $\mathrm{ND}$ \\
\hline & Cheongju & $0.50 \pm 0.00^{\mathrm{a}}$ & $\mathrm{ND}$ & $0.05 \pm 0.00^{h}$ & $0.011 \pm 0.00^{c}$ & $3.34 \pm 0.17^{\mathrm{a}}$ & $\mathrm{ND}$ \\
\hline & Yesan & $0.18 \pm 0.00^{f}$ & $0.020 \pm 0.00^{c}$ & $0.12 \pm 0.00^{e}$ & $0.032 \pm 0.00^{\mathrm{a}}$ & $3.04 \pm 0.03^{b}$ & $0.65 \pm 0.07^{\mathrm{a}}$ \\
\hline & Jangsu & $0.21 \pm 0.00^{\mathrm{d}}$ & $0.026 \pm 0.00^{\mathrm{b}}$ & $0.07 \pm 0.00^{g}$ & $0.026 \pm 0.00^{\mathrm{b}}$ & $1.16 \pm 0.03^{\mathrm{f}}$ & $0.16 \pm 0.02^{b}$ \\
\hline & Jangseong & $0.26 \pm 0.00^{\mathrm{b}}$ & $\mathrm{ND}$ & $0.13 \pm 0.00^{\mathrm{d}}$ & $0.010 \pm 0.00^{\mathrm{cd}}$ & $1.26 \pm 0.05^{\mathrm{f}}$ & $\mathrm{ND}$ \\
\hline & Yeongcheon & $0.20 \pm 0.00^{\mathrm{d}}$ & $\mathrm{ND}$ & $0.18 \pm 0.00^{b}$ & $0.032 \pm 0.00^{\mathrm{a}}$ & $1.92 \pm 0.03^{\mathrm{e}}$ & $\mathrm{ND}$ \\
\hline & Geochang & $0.19 \pm 0.00^{\mathrm{e}}$ & ND & $0.11 \pm 0.00^{f}$ & $0.012 \pm 0.00^{c}$ & $2.57 \pm 0.00^{c}$ & $\mathrm{ND}$ \\
\hline
\end{tabular}

\footnotetext{
${ }^{1)}$ All values are expressed as mean \pm SD of triplicate determinations. Means with different superscripts within a column (a-h) are significantly different at $\mathrm{p}<0.05$ by Duncan's multiple range test.
}

${ }^{2}$ Not detected.

이를 나타내었고(p>0.05), 특히 여산(충남) 지역에서 전반 적으로 높은 함량을 나타냈고 포천(경기도) 지역에서 칼슘, 철, 아연을 제외하고 다른 지역에 비해 낮은 함량을 나타내 었다. 또한 무기성분별 유의적으로 가장 높은 지역을 보면, 칼슘, 마그네슘, 구리, 셀레늄은 충남의 여산(각각 3.15 $\mathrm{mg} / 100 \mathrm{~g}, 2.30 \mathrm{mg} / 100 \mathrm{~g}, 0.03 \mathrm{mg} / 100 \mathrm{~g}, 0.65 \mathrm{\mu g} / 100 \mathrm{~g}$ ), 인은 충북의 청주와 충남의 여산(각각 $12.67 \mathrm{mg} / 100 \mathrm{~g}$,
$12.83 \mathrm{mg} / 100 \mathrm{~g})$, 나트륨은 경북의 영천 $(3.65 \mathrm{mg} / 100 \mathrm{~g})$, 칼륨은 전북의 장수 $(193.66 \mathrm{mg} / 100 \mathrm{~g})$, 철과 몰리브덴은 충북의 청주(각각 $0.50 \mathrm{mg} / 100 \mathrm{~g}, 3.34 \mu \mathrm{g} / 100 \mathrm{~g}$ ), 망간은 강원도의 춘천 $(0.029 \mathrm{mg} / 100 \mathrm{~g})$, 아연은 경기도의 포천 $(0.18$ $\mathrm{mg} / 100 \mathrm{~g}$ )에서 가장 높은 값을 나타내었다. Ji 등(4)과 Kim 등(9)의 연구에 의하면 5 개 지역에서 생산한 사과의 후지 품종의 무기성분을 비교한 결과, $\mathrm{Ji}$ 등은 충남 지역에서 
Table 8. Comparison of macro mineral contents of tomato, paprika and pepper varieties

\begin{tabular}{ccccccc}
\hline Sample & Varieties & $\begin{array}{c}\mathrm{Ca} \\
(\mathrm{mg} / 100 \mathrm{~g})\end{array}$ & $\begin{array}{c}\mathrm{P} \\
(\mathrm{mg} / 100 \mathrm{~g})\end{array}$ & $\begin{array}{c}\mathrm{Na} \\
(\mathrm{mg} / 100 \mathrm{~g})\end{array}$ & $\begin{array}{c}\mathrm{K} \\
(\mathrm{mg} / 100 \mathrm{~g})\end{array}$ & $\begin{array}{c}\mathrm{Mg} \\
(\mathrm{mg} / 100 \mathrm{~g})\end{array}$ \\
\hline \multirow{5}{*}{ Tomato } & Dafnis & $3.94 \pm 0.05^{\mathrm{e})}$ & $23.11 \pm 0.20^{\mathrm{e}}$ & $4.98 \pm 0.01^{\mathrm{e}}$ & $282.61 \pm 1.66^{\mathrm{e}}$ & $5.59 \pm 0.02^{\mathrm{f}}$ \\
& 244 & $5.06 \pm 0.05^{\mathrm{d}}$ & $35.10 \pm 0.12^{\mathrm{b}}$ & $4.13 \pm 0.04^{\mathrm{f}}$ & $303.12 \pm 1.80^{\mathrm{d}}$ & $6.64 \pm 0.04^{\mathrm{e}}$ \\
& Bravo TY & $7.59 \pm 0.11^{\mathrm{b}}$ & $37.83 \pm 0.52^{\mathrm{a}}$ & $7.74 \pm 0.09^{\mathrm{c}}$ & $390.55 \pm 5.13^{\mathrm{a}}$ & $12.65 \pm 0.07^{\mathrm{a}}$ \\
& Minichal & $5.58 \pm 0.08^{\mathrm{c}}$ & $33.47 \pm 0.29^{\mathrm{c}}$ & $8.58 \pm 0.05^{\mathrm{b}}$ & $342.40 \pm 3.54^{\mathrm{b}}$ & $10.16 \pm 0.12^{\mathrm{b}}$ \\
& Dotaerang Dia & $3.85 \pm 0.01^{\mathrm{e}}$ & $33.24 \pm 0.06^{\mathrm{c}}$ & $6.25 \pm 0.03^{\mathrm{d}}$ & $331.69 \pm 5.84^{\mathrm{c}}$ & $8.91 \pm 0.13^{\mathrm{d}}$ \\
& Jico & $7.70 \pm 0.22^{\mathrm{b}}$ & $25.78 \pm 0.24^{\mathrm{d}}$ & $10.82 \pm 0.12^{\mathrm{a}}$ & $328.93 \pm 4.83^{\mathrm{c}}$ & $9.40 \pm 0.26^{\mathrm{c}}$ \\
& Tabol & $7.93 \pm 0.17^{\mathrm{a}}$ & $18.75 \pm 0.19^{\mathrm{f}}$ & $2.60 \pm 0.00^{\mathrm{g}}$ & $248.49 \pm 2.99^{\mathrm{f}}$ & $4.71 \pm 0.07^{\mathrm{g}}$ \\
\hline \multirow{3}{*}{ Paprika } & Jacarlo (red) & $5.78 \pm 0.15^{\mathrm{d}}$ & $26.74 \pm 0.61^{\mathrm{a}}$ & $1.36 \pm 0.03^{\mathrm{e}}$ & $239.00 \pm 2.78^{\mathrm{b}}$ & $9.27 \pm 0.23^{\mathrm{b}}$ \\
& Nagano (red) & $6.55 \pm 0.06^{\mathrm{c}}$ & $21.67 \pm 0.11^{\mathrm{d}}$ & $3.78 \pm 0.04^{\mathrm{a}}$ & $217.27 \pm 1.02^{\mathrm{c}}$ & $7.66 \pm 0.03^{\mathrm{c}}$ \\
& Lunik (yellow) & $6.91 \pm 0.12^{\mathrm{b}}$ & $23.60 \pm 0.20^{\mathrm{c}}$ & $2.86 \pm 0.03^{\mathrm{c}}$ & $208.07 \pm 3.76^{\mathrm{d}}$ & $7.23 \pm 0.09^{\mathrm{d}}$ \\
& Sven (yellow) & $7.36 \pm 0.12^{\mathrm{a}}$ & $21.98 \pm 0.26^{\mathrm{d}}$ & $1.97 \pm 0.02^{\mathrm{d}}$ & $219.59 \pm 3.78^{\mathrm{c}}$ & $7.77 \pm 0.12^{\mathrm{c}}$ \\
& Orandino (orange) & $7.23 \pm 0.10^{\mathrm{a}}$ & $25.49 \pm 0.39^{\mathrm{b}}$ & $3.01 \pm 0.04^{\mathrm{b}}$ & $262.23 \pm 3.66^{\mathrm{a}}$ & $9.59 \pm 0.08^{\mathrm{a}}$ \\
\hline & Colorjjang & $11.91 \pm 0.10^{\mathrm{c}}$ & $69.09 \pm 0.45^{\mathrm{b}}$ & $4.92 \pm 1.16^{\mathrm{a}}$ & $521.11 \pm 0.05^{\mathrm{b}}$ & $32.05 \pm 0.18^{\mathrm{b}}$ \\
& Daekwonseoneon & $14.27 \pm 0.07^{\mathrm{a}}$ & $79.57 \pm 0.44^{\mathrm{a}}$ & $4.98 \pm 0.48^{\mathrm{a}}$ & $638.59 \pm 0.06^{\mathrm{a}}$ & $37.30 \pm 0.16^{\mathrm{a}}$ \\
& Gilsang & $9.20 \pm 0.21^{\mathrm{d}}$ & $29.45 \pm 0.42^{\mathrm{d}}$ & $3.05 \pm 1.87^{\mathrm{c}}$ & $244.04 \pm 0.02^{\mathrm{d}}$ & $9.22 \pm 0.14^{\mathrm{d}}$ \\
& Cheongyang & $12.65 \pm 0.21^{\mathrm{b}}$ & $42.81 \pm 0.56^{\mathrm{c}}$ & $3.77 \pm 4.56^{\mathrm{b}}$ & $306.23 \pm 0.10^{\mathrm{c}}$ & $14.05 \pm 0.20^{\mathrm{c}}$ \\
\hline
\end{tabular}

${ }^{11}$ All values are expressed as mean $\pm \mathrm{SD}$ of triplicate determinations. Means with different superscripts within a column $(\mathrm{a}-\mathrm{g})$ are significantly different at $\mathrm{p}<0.05$ by $D$ uncan's multiple range test.

전반적으로 높은 함량을 보였지만 Kim 등은 충남 지역에서 상대적으로 낮은 함량을 보였다는 상반되는 결과를 나타내 었고, $\mathrm{ji}$ 등의 연구에서 같은 경상북도 지역이라도 생산도시 가 다르면 무기성분의 함량에도 차이를 보이는 결과 값을 나타내었다. 이는 Ikebe 등의 연구(24)처럼 아주 미량으로 존재하는 성분이지만 품종이나 지역에 따라 수십 배의 차이 를 보이고 있는 결과를 보고한 바와 같이 동일한 품종이라 할지라도 행정 구역상 구분한 지역 간 차이뿐만 아니라 같은 지역이라도 생산도시에 따른 차이가 있고 여기에 재배 조건이나 토양, 용수 등 재배 환경적 영향에 의한 차이도 있을 것이라 사료된다.

\section{채소류의 품종별 무기질 함량}

무기질 함량을 분석한 채소류는 모두 열매채소로 토마토 는 7가지 품종(데프니스, 244, 브라보TY, 미니찰, 도태랑다 이아, 지코, 다볼), 파프리카는 5 가지 품종(쟈칼로, 나가노, 루니크, 스벨, 오란디노), 고추는 4가지 품종(칼라짱, 대권 선원, 길상, 청양)으로 그 결과를 다량무기질은 Table 8 , 미량무기질은 Table 9에 나타내었다. 특히, 채소류의 무기 질은 칼륨 > 인 > 마그네슘 > 칼슘 순으로 높은 함량을 보였다.

\section{토마토}

토마토의 다량무기질 평균값은 칼슘 $5.95 \mathrm{mg} / 100 \mathrm{~g}$, 인
$29.61 \mathrm{mg} / 100 \mathrm{~g}$, 나트륨 $6.44 \mathrm{mg} / 100 \mathrm{~g}$, 칼륨 $318.26 \mathrm{mg} / 100$ $\mathrm{g}$, 마그네슘 $8.30 \mathrm{mg} / 100 \mathrm{~g}$ 이었고, 미량무기질 평균값은 철 $0.53 \mathrm{mg} / 100 \mathrm{~g}$, 망간 $0.07 \mathrm{mg} / 100 \mathrm{~g}$, 아연 $0.29 \mathrm{mg} / 100$ $\mathrm{g}$, 구리 $0.03 \mathrm{mg} / 100 \mathrm{~g}$, 몰리브덴 $3.61 \mu \mathrm{g} / 100 \mathrm{~g}$, 셀레늄 $0.14 \mu \mathrm{g} / 100 \mathrm{~g}$ 이었으며, 나트륨은 본 연구에서 분석한 과채 류의 평균값 중 가장 높은 함량을 나타내었다. 또한 무기성 분별 유의적으로 가장 높은 품종을 보면, 칼슘과 셀레늄은 다볼(각각 $7.93 \mathrm{mg} / 100 \mathrm{~g}, 0.97 \mathrm{\mu g} / 100 \mathrm{~g}$ ), 인, 칼륨, 마그네슘, 철, 망간은 브라보 $\mathrm{TY}$ (각각 $37.83 \mathrm{mg} / 100 \mathrm{~g}, 390.55 \mathrm{mg} / 100$ $\mathrm{g}, 12.65 \mathrm{mg} / 100 \mathrm{~g}, 0.94 \mathrm{mg} / 100 \mathrm{~g}, 0.13 \mathrm{mg} / 100 \mathrm{~g}$ ), 나트륨, 아연, 구리는 지코(각각 $10.82 \mathrm{mg} / 100 \mathrm{~g}, 0.80 \mathrm{mg} / 100 \mathrm{~g}$, $0.058 \mathrm{mg} / 100 \mathrm{~g})$, 몰리브덴은 도태랑다이아 $(9.01 \mathrm{\mu g} / 100 \mathrm{~g})$ 이었고, 그 중 아연, 몰리브덴, 셀레늄은 평균값과 2.7, 2.5, 7.0배의 큰 차이로 높은 값을 나타내었다. 특히 핑크계(동양 계) 토마토인 도태랑다이아 품종은 몰리브덴 성분이 본 연 구에서 분석한 과채류 중 가장 높은 함량으로 몰리브덴 1 일 영양섭취량 $(25 \mu \mathrm{g} / 100 \mathrm{~g})$ 의 $36 \%$ 를 공급할 수 있고, 대추 토마토인 지코 품종은 나트륨과 아연 성분, 브라보 TY 품종 은 철 성분이 가장 높은 함량으로 그 1 일 영양섭취량 $(2,000$ $\mathrm{mg} / 100 \mathrm{~g}, 8.5 \mathrm{mg} / 100 \mathrm{~g}, 12 \mathrm{mg} / 100 \mathrm{~g}$ )의 $9.2 \%, 9.4 \%, 7.8 \%$ 를 공급할 수 있을 것으로 생각된다. 토마토는 인, 칼륨, 마그네 슘, 철, 아연 성분에서 레드계(유럽계) 토마토인 데프니스와 다볼은 낮은 함량을 나타낸 반면, 방울 또는 대추토마토인 미니찰, 지코, 브라보TY에서는 높은 함량을 나타내어 형태 
Table 9. Comparison of micro mineral contents of tomato, paprika and pepper varieties

\begin{tabular}{|c|c|c|c|c|c|c|c|}
\hline Sample & Varieties & $\begin{array}{c}\mathrm{Fe} \\
(\mathrm{mg} / 100 \mathrm{~g})\end{array}$ & $\begin{array}{c}\mathrm{Mn} \\
(\mathrm{mg} / 100 \mathrm{~g})\end{array}$ & $\begin{array}{c}\mathrm{Zn} \\
(\mathrm{mg} / 100 \mathrm{~g})\end{array}$ & $\begin{array}{c}\mathrm{Cu} \\
(\mathrm{mg} / 100 \mathrm{~g})\end{array}$ & $\begin{array}{c}\text { Mo } \\
(\mu \mathrm{g} / 100 \mathrm{~g})\end{array}$ & $\begin{array}{c}\text { Se } \\
(\mu \mathrm{g} / 100 \mathrm{~g})\end{array}$ \\
\hline \multirow{7}{*}{ Tomato } & Dafnis & $0.39 \pm 0.02^{\mathrm{d} 1)}$ & $0.082 \pm 0.00^{b}$ & $0.13 \pm 0.00^{f}$ & $0.009 \pm 0.00^{f}$ & $5.21 \pm 0.12^{\mathrm{c}}$ & $\mathrm{ND}^{2)}$ \\
\hline & 244 & $0.49 \pm 0.00^{c}$ & $0.078 \pm 0.00^{\text {cd }}$ & $0.20 \pm 0.00^{d}$ & $\mathrm{ND}$ & $\mathrm{ND}$ & $\mathrm{ND}$ \\
\hline & Bravo TY & $0.94 \pm 0.01^{\mathrm{a}}$ & $0.126 \pm 0.00^{\mathrm{a}}$ & $0.30 \pm 0.00^{c}$ & $0.050 \pm 0.00^{b}$ & $2.92 \pm 0.07^{\mathrm{d}}$ & $\mathrm{ND}$ \\
\hline & Minichal & $0.48 \pm 0.03^{\mathrm{c}}$ & $0.082 \pm 0.00^{\mathrm{bc}}$ & $0.33 \pm 0.01^{\mathrm{b}}$ & $0.046 \pm 0.00^{c}$ & $6.11 \pm 0.07^{b}$ & $\mathrm{ND}$ \\
\hline & Dotaerang Dia & $0.50 \pm 0.00^{c}$ & $0.076 \pm 0.00^{\mathrm{d}}$ & $0.18 \pm 0.00^{\mathrm{e}}$ & $0.041 \pm 0.00^{\mathrm{d}}$ & $9.01 \pm 0.76^{\mathrm{a}}$ & $\mathrm{ND}$ \\
\hline & Jico & $0.59 \pm 0.00^{\mathrm{b}}$ & $0.049 \pm 0.00^{e}$ & $0.80 \pm 0.01^{\mathrm{a}}$ & $0.058 \pm 0.00^{\mathrm{a}}$ & $1.86 \pm 0.04^{\mathrm{e}}$ & $\mathrm{ND}$ \\
\hline & Tabol & $0.31 \pm 0.00^{\mathrm{e}}$ & $0.024 \pm 0.00^{g}$ & $0.13 \pm 0.00^{g}$ & $0.037 \pm 0.00^{\mathrm{e}}$ & $0.16 \pm 0.02^{\mathrm{g}}$ & $0.97 \pm 0.06^{\mathrm{a}}$ \\
\hline \multirow{5}{*}{ Paprika } & Jacarlo & $0.46 \pm 0.01^{\mathrm{b}}$ & $0.064 \pm 0.01^{\mathrm{b}}$ & $0.33 \pm 0.00^{\mathrm{a}}$ & $0.036 \pm 0.00^{\mathrm{a}}$ & $3.12 \pm 0.17^{\mathrm{c}}$ & $\mathrm{ND}$ \\
\hline & Nagano & $0.47 \pm 0.01^{\mathrm{b}}$ & $0.025 \pm 0.00^{\mathrm{e}}$ & $0.22 \pm 0.00^{d}$ & $0.014 \pm 0.00^{c}$ & $3.26 \pm 0.04^{c}$ & $\mathrm{ND}$ \\
\hline & Lunik & $0.44 \pm 0.02^{\mathrm{b}}$ & $0.113 \pm 0.00^{\mathrm{a}}$ & $0.27 \pm 0.00^{c}$ & $0.022 \pm 0.00^{b}$ & $3.11 \pm 0.01^{\mathrm{c}}$ & $\mathrm{ND}$ \\
\hline & Sven & $0.41 \pm 0.01^{\mathrm{b}}$ & $0.036 \pm 0.00^{\mathrm{d}}$ & $0.22 \pm 0.00^{\mathrm{d}}$ & $0.016 \pm 0.00^{c}$ & $4.90 \pm 0.08^{\mathrm{a}}$ & $\mathrm{ND}$ \\
\hline & Orandino & $0.59 \pm 0.14^{\mathrm{a}}$ & $0.054 \pm 0.01^{c}$ & $0.29 \pm 0.00^{b}$ & $0.018 \pm 0.00^{b c}$ & $3.69 \pm 0.06^{b}$ & $\mathrm{ND}$ \\
\hline \multirow{4}{*}{ Pepper } & Colorjjang & $0.74 \pm 0.01^{\mathrm{a}}$ & $0.177 \pm 0.00^{b}$ & $0.52 \pm 0.01^{b}$ & $0.109 \pm 0.00^{\mathrm{a}}$ & $6.42 \pm 0.14^{\mathrm{a}}$ & $\mathrm{ND}$ \\
\hline & Daekwonseoneon & $0.11 \pm 0.00^{\mathrm{d}}$ & $0.245 \pm 0.00^{\mathrm{a}}$ & $0.72 \pm 0.05^{\mathrm{a}}$ & $0.112 \pm 0.00^{\mathrm{a}}$ & $5.21 \pm 0.53^{\mathrm{b}}$ & $\mathrm{ND}$ \\
\hline & Gilsang & $0.26 \pm 0.01^{c}$ & $0.017 \pm 0.00^{d}$ & $0.29 \pm 0.01^{\mathrm{c}}$ & $0.055 \pm 0.00^{\mathrm{b}}$ & $4.68 \pm 0.13^{\mathrm{c}}$ & $1.00 \pm 0.03^{b}$ \\
\hline & Cheongyang & $0.40 \pm 0.01^{\mathrm{b}}$ & $0.041 \pm 0.00^{c}$ & $0.22 \pm 0.02^{\mathrm{d}}$ & $0.052 \pm 0.00^{b}$ & $1.45 \pm 0.03^{\mathrm{d}}$ & $1.38 \pm 0.04^{\mathrm{a}}$ \\
\hline
\end{tabular}

${ }^{11}$ All values are expressed as mean \pm SD of triplicate determinations. Means with different superscripts within a column (a-g) are significantly different at $p<0.05$ by $D u n c a n$ 's multiple range test.

${ }^{2}$ Not detected.

적으로 차이를 보이는 품종간의 상반되는 결과를 나타내었 다. 이는 일반토마토라 볼 수 있는 레드계 토마토는 유통기 간을 고려해 완숙 이전에 수확을 하는 반면 방울 또는 대추 토마토는 완숙된 상태에서 수확하기 때문으로 사료된다.

\section{파프리카}

파프리카의 다량무기질 평균값은 칼슘 $6.77 \mathrm{mg} / 100 \mathrm{~g}$, 인 $23.90 \mathrm{mg} / 100 \mathrm{~g}$, 나트륨 $2.60 \mathrm{mg} / 100 \mathrm{~g}$, 칼륨 229.23 $\mathrm{mg} / 100 \mathrm{~g}$, 마그네슘 $8.31 \mathrm{mg} / 100 \mathrm{~g}$ 이었고, 미량무기질 평균 값은 철 $0.47 \mathrm{mg} / 100 \mathrm{~g}$, 망간 $0.06 \mathrm{mg} / 100 \mathrm{~g}$, 아연 0.27 $\mathrm{mg} / 100 \mathrm{~g}$, 구리 $0.02 \mathrm{mg} / 100 \mathrm{~g}$, 몰리브덴 $3.61 \mu \mathrm{g} / 100 \mathrm{~g}$ 이었 으며 셀레늄은 측정되지 않았다. 또한 무기성분별 유의적 으로 가장 높은 품종을 보면, 칼슘은 스벤, 오란디노(각각 $7.36 \mathrm{mg} / 100 \mathrm{~g}, 7.23 \mathrm{mg} / 100 \mathrm{~g}$ ), 인, 아연, 구리는 쟈칼로(각각 $26.74 \mathrm{mg} / 100 \mathrm{~g}, 0.33 \mathrm{mg} / 100 \mathrm{~g}, 0.036 \mathrm{mg} / 100 \mathrm{~g}$ ), 나트륨은 나가노 $(3.78 \mathrm{mg} / 100 \mathrm{~g})$, 칼륨, 마그네슘, 철은 오란디노(각 각 $262.23 \mathrm{mg} / 100 \mathrm{~g}, 9.59 \mathrm{mg} / 100 \mathrm{~g}, 0.59 \mathrm{mg} / 100 \mathrm{~g}$ ), 망간은 루니크 $(0.113 \mathrm{mg} / 100 \mathrm{~g})$, 몰리브덴은 스벤 $(4.90 \mu \mathrm{g} / 100 \mathrm{~g})$ 이 었다. 특히, 파프리가 색깔별로 상관관계는 보이지 않고 품종 간에 유의차는 있었으나 큰 차이 없이 비슷한 함량을 나타내어 색깔보다는 품종에 따른 차이로 사료되며, 주황 색인 오란디노 품종이 전반적으로 높은 무기질 함량을 나타 내었다.
고추

고추의 다량무기질 평균값은 칼슘 $12.01 \mathrm{mg} / 100 \mathrm{~g}$, 인 $55.23 \mathrm{mg} / 100 \mathrm{~g}$, 나트륨 $4.18 \mathrm{mg} / 100 \mathrm{~g}$, 칼륨 $427.49 \mathrm{mg} / 100 \mathrm{~g}$, 마그네슘 $23.16 \mathrm{mg} / 100 \mathrm{~g}$ 이었고, 미량무기질 평균값은 철 $0.38 \mathrm{mg} / 100 \mathrm{~g}$, 망간 $0.12 \mathrm{mg} / 100 \mathrm{~g}$, 아연 $0.44 \mathrm{mg} / 100 \mathrm{~g}$, 구리 $0.08 \mathrm{mg} / 100 \mathrm{~g}$, 몰리브덴 $4.44 \mathrm{\mu g} / 100 \mathrm{~g}$, 셀레늄 0.60 $\mu \mathrm{g} / 100 \mathrm{~g}$ 이었다. 또한 무기성분별 유의적으로 가장 높은 품종을 보면, 칼슘, 인, 칼륨, 마그네슘, 망간, 아연은 대권선 언(각각 $14.27 \mathrm{mg} / 100 \mathrm{~g}, 79.57 \mathrm{mg} / 100 \mathrm{~g}, 638.59 \mathrm{mg} / 100$ $\mathrm{g}, 37.30 \mathrm{mg} / 100 \mathrm{~g}, 0.25 \mathrm{mg} / 100 \mathrm{~g}, 0.72 \mathrm{mg} / 100 \mathrm{~g})$, 나트륨은 대권선언과 칼라짱 (각각 $4.98 \mathrm{mg} / 100 \mathrm{~g}, 4.92 \mathrm{mg} / 100 \mathrm{~g}$ ), 철은 칼라짱 $(0.74 \mathrm{mg} / 100 \mathrm{~g})$, 구리는 대권선언과 칼라짱(각 각 $0.112 \mathrm{mg} / 100 \mathrm{~g}, 0.109 \mathrm{mg} / 100 \mathrm{~g}$ ), 몰리브덴은 칼라짱 $(6.42 \mu \mathrm{g} / 100 \mathrm{~g})$, 셀레늄은 청양 $(1.38 \mu \mathrm{\mu g} / 100 \mathrm{~g})$ 이었다. 특히 대권선언은 인, 칼륨, 마그네슘 성분이 본 연구에서 분석한 과채류 중 가장 높은 값을 나타내어 인, 칼륨, 마그네슘의 1일 영양섭취량 $(700 \mathrm{mg} / 100 \mathrm{~g}, 3,500 \mathrm{mg} / 100 \mathrm{~g}, 315 \mathrm{mg} / 100$ $\mathrm{g}$ )의 $11.4 \%, 18.3 \%, 11.8 \%$ 를 공급할 수 있을 것으로 생각한 다. 적색 품종인 칼라짱과 대권선언에서 셀레늄을 제외한 모든 무기성분이 청색 품종 보다 높은 함량을 보였고, 청색 품종 중 청양은 오이고추라고 불리는 길상보다 아연, 구리, 몰리브덴을 제외하고 1.2-2.4배 높은 값을 나타내었다. 청양 과 길상은 국가표준식품성분표(제9개정판)(6)에 나온 동일 품종과 비교한 결과 칼슘, 망간, 아연, 몰리브덴을 제외하고 
청양 품종이 더 높은 값을 나타낸 것으로 본 연구에서 분석 한 경향과 비슷하였다.

\section{칼슘과 다른 무기질과의 비교}

칼슘과 인의 비율은 다음과 같다. 칼슘의 흡수에 대해 칼슘과 인의 비율이 크게 영향을 미치는데, 동물실험에서 인의 섭취량이 칼슘의 섭취량에 비해 너무 높으면 칼슘의 흡수를 저해하고 빼의 손실이 일어난다고 하였다(25). 칼슘 은 골격과 치아의 구성성분으로 체내 칼슘 함량의 약 $99 \%$ 가 여기에 존재하며 부족하면 골다공증의 원인이 된다. 국 민건강조사에 따르면 칼슘은 대표적인 섭취부족 영양소로 유기산, 비타민 D3는 그 흡수를 돕지만 식이섬유, phytate와 함께 섭취 시 흡수를 저해한다고 한다(3,7). 또한 인은 체내 에 $85 \%$ 는 칼슘과 결합하여 골격과 치아를 구성하며 대사면 에서 칼슘과 밀접한 관련이 있는 영양소로 우리나라 영양권 장량에서 칼슘 : 인의 섭취비율은 $1: 1$ 로 권장되고 있으나 2007년 한국인의 칼슘과 인의 섭취비는 $1: 2.1-2.3$ 으로 인의 섭취가 다소 많은 편이었다 $(1,7,25)$. 본 연구에서 보여준 과채류의 칼슘과 철 비율의 평균값을 보면, 딸기는 1.8(1.3-2.2), 복숭아는 4.9(1.4-8.0), 포도는 2.2(1.6-3.2), 사 과는 3.6(1.9-4.5), 토마토는 5.4(2.4-8.6), 파프리카는 $3.6(3.0-4.6)$, 고추는 4.5(3.2-5.6)이었다. 모든 과채류가 인의 함량이 칼슘보다 더 높았으며 평균적으로 인의 함량이 높은
것은 토마토이었고, 비율이 $1: 1$ 과 가장 근접한 것은 딸기 중 샤롯데 품종(1.3)이었다. 칼슘의 섭취가 증가하면 칼슘 배설이 증가하지만 칼슘을 보충하여 칼슘과 인의 중량비가 $1: 1.5$ 에서 $1: 0.8$ 이 되면 칼슘의 배설이 증가함에도 흡수율 이 크게 감소하지 않았다는 보고결과도 있듯(7) 과채류 섭 취 시 추가적인 칼슘 섭취가 잘 이루어져야 칼슘의 흡수율 이 방해받지 않으며, 인은 자연식품에서 가공식품에 이르 기까지 과다하게 섭취하는 경우가 많기 때문에 영양강화식 품이나 영양제를 따로 섭취할 필요가 없다고 생각된다.

칼슘과 마그네슘의 비율은 다음과 같다. 마그네슘은 신 경과 근육 기능에 중요한 역할을 하는 여러 효소의 구성원 으로 신경과 근육의 흥분성을 정상화하는데 칼슘과 협동적 또는 길항적으로 작용하며 부족 시 근육이 약해지고 통증이 올 수 있다 $(1,6)$. 우리나라 영양권장량에서 칼슘과 마그네 슘의 권장섭취비율은 $2: 1$ 이고 칼슘과 마그네슘의 섭취비 율이 $4: 1$ 이상이 되면 소화 장기에서 마그네슘의 흡수율이 감소되는데 이는 칼슘 섭취를 높이면 혈청 및 대퇴골의 마그네슘 함량이 유의적으로 감소했다는 보고도 있다 $(1,25)$. 본 연구에서 보여준 과채류의 칼슘과 마그네슘 비율 의 평균값을 보면 딸기는 $1.5(1.2-2.1)$, 복숭아는 1.1(0.7-2.1), 포도는 2.5(1.3-5.3), 사과는 1.6(1.0-2.4), 토마 토는 0.8(0.4-1.7), 파프리카는 $0.8(0.6-1.0)$, 고추는 0.7(0.4-1.0)이었다. 과일류는 칼슘 함량이 더 높았고 채소류
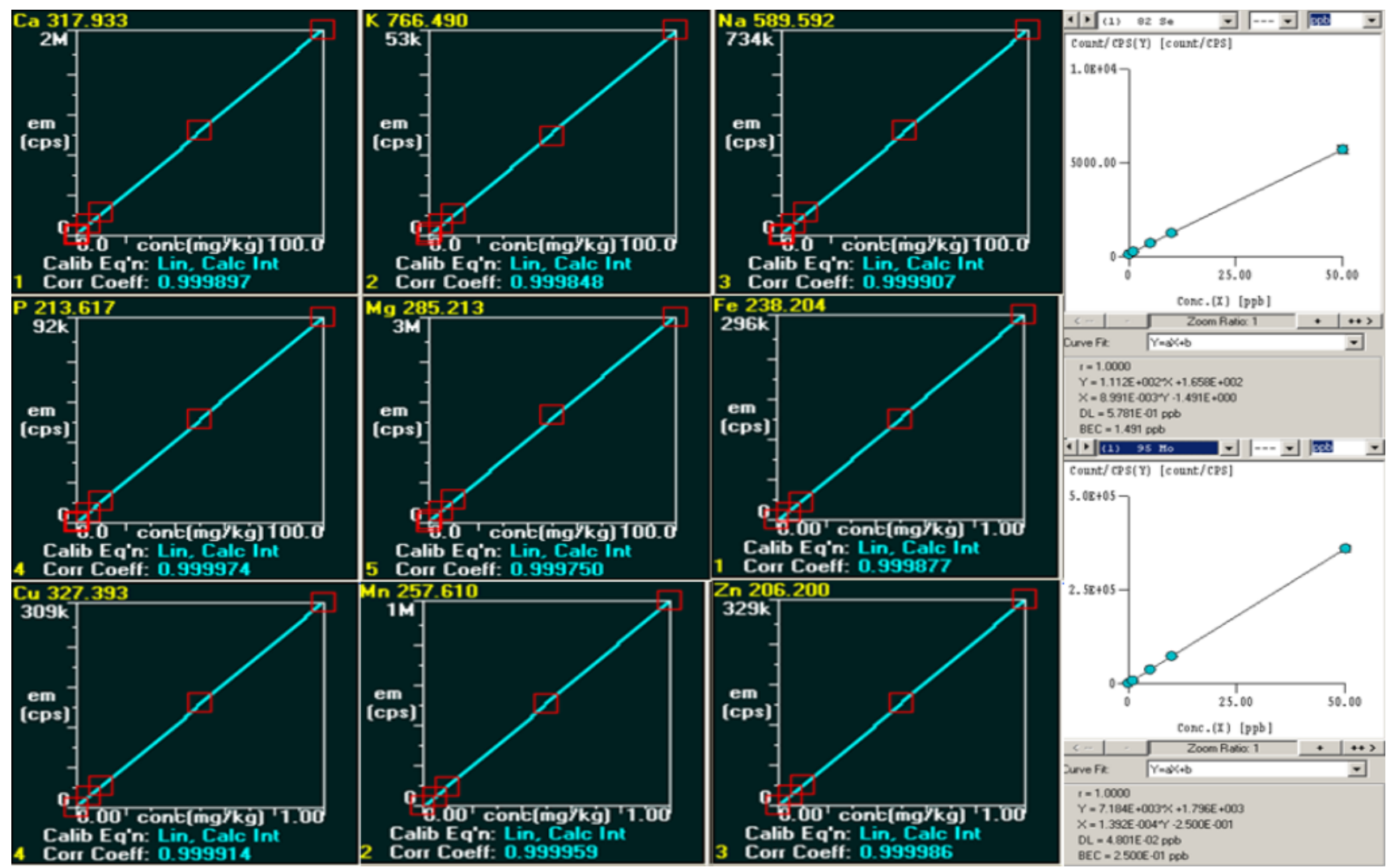

Fig. 1. Calibration curve and correlation coefficient of mineral standard solution. 
는 마그네슘 함량이 더 높았으며, 권장섭취비율과 유사한 비율을 갖는 것은 딸기의 샤롯데 품종(2.1), 복숭아의 환타 지아 품종(2.1), 포도의 청향(2.1)과 스위트드림(2.0) 품종이 었고, 칼슘과 마그네슘의 비율이 $4: 1$ 이상을 갖는 것은 포도의 옥랑(5.3)과 $\mathrm{MBA}(4.3)$ 품종이었다.

\section{요 약}

본 연구는 한국인 다빈도 섭취 과일인 딸기, 복숭아, 포도, 사과의 품종별, 산지별 35종 및 채소류인 토마토, 파프리카, 고추의 품종별로 17 종을 선정하고, 소비자들이 섭취하는 가식부만 전처리한 후 무기질 11 종의 함량을 분석, 비교하 였다. 무기질은 마이크로웨이브법을 이용하여 시료를 전처 리한 후 다량 및 미량무기질은 ICP-OES, 초미량무기질은 ICP-MS를 이용하여 분석하였다. 과일류는 $\mathrm{K}>\mathrm{P}>\mathrm{Ca}>\mathrm{Mg}$ 순, 채소류는 $\mathrm{K}>\mathrm{P}>\mathrm{Mg}>\mathrm{Ca}$ 순으로 무기질 함량이 높았고, 과일류보다 채소류에서 무기질 함량이 높았으나 항산화 기능을 갖는 $\mathrm{Se}$ 은 과일류에서 더 높은 함량을 나타내었다. 품종별로 살펴보면, 딸기는 금실 품종이 $\mathrm{Ca}(23.52 \mathrm{mg} / 100$ g), P(45.29 mg/100 g), Mg(20.05 mg/100 g), Fe(0.87 mg/100 $\mathrm{g}), \mathrm{Mn}(0.58 \mathrm{mg} / 100 \mathrm{~g}), \mathrm{Mo}(8.44 \mathrm{\mu g} / 100 \mathrm{~g})$ 성분에서 과일류 중 가장 높은 값을 나타냈고, 복숭아는 천도 품종(천홍, 선프레, 환타지아)과 백도 중 천중도 품종이 다량무기질 함량이 높았으며, 포도는 흑색의 자옥과 청색의 샤인머스 켓 품종이 다량무기질 $(\mathrm{Ca}, \mathrm{P}, \mathrm{K}, \mathrm{Mg})$ 함량이 높았고, 그 중 $\mathrm{Ca}(12.28 \mathrm{mg} / 100 \mathrm{~g})$ 과 $\mathrm{K}(241.42 \mathrm{mg} / 100 \mathrm{~g})$ 은 샤인머스켓 품종에서 가장 높은 값을 나타냈다. 사과는 가을사과인 자 홍, 아리수, 홍로 품종에서 다량무기질 함량이 높았고, 여름 사과인 썸머킹, 쓰가루 품종에서 미량무기질 함량이 높았 으며, 동일한 품종(홍로)도 산지별로 그 함량이 다르다는 것을 알 수 있었다. 토마토는 $\mathrm{K}, \mathrm{Mg}, \mathrm{Fe}, \mathrm{Zn}$ 성분의 함량이 높은 레드계 토마토(데프니스와 다볼)와 방울 또는 대추토 마토(미니찰, 지코, 브라보TY)가 상반되는 결과를 나타내 었으며, 파프리카는 빨간색, 노란색, 주황색의 색깔별 차이 보다는 품종에 따른 함량의 차이인 것을 알 수 있었다. 고추 는 청색 품종(청양, 길상)보다 적색 품종(칼라짱, 대권선언) 에서 무기질 함량이 높았으며 그 중 대권선언은 P(79.57 $\mathrm{mg} / 100 \mathrm{~g}), \mathrm{K}(638.59 \mathrm{mg} / 100 \mathrm{~g}), \mathrm{Mg}(37.30 \mathrm{mg} / 100 \mathrm{~g})$ 성분이 본 연구에서 분석한 과일류와 채소류 중 가장 높은 함량을 나타내었다. 이 무기질 분석 자료는 국민에게 식생활의 지 침서로서 기본 영양정보를 제공하는 국가표준식품성분표 발간을 위한 것으로 분석법 검증을 위한 직선성, 정확성, 정밀성을 확인하였고 이를 통해 신뢰도 높은 결과 값을 도출하여, 본 연구에서 분석한 무기질 자료는 식품성분표 $\mathrm{DB}$ 구축과 국가표준식품성분표 책자 발행을 위한 신뢰성 있는 기초 자료로 활용될 수 있을 것으로 기대된다.

\section{감사의 글}

본 연구는 농촌진흥청 공동연구사업(과제번호: PJ01342707) 의 지원에 의해 수행되었으며, 이에 감사드립니다.

\section{References}

1. Kim OH, Kim ES (2003) Astudy on the mineral content of calcium-fortified foods in korea. J Korean Soc Food Sci Nutr, 32, 96-101

2. Choi YM (2015) Management of quality control and food composition(mineral and fatty acid) analysis for the 9th national standard food composition. Final Report of RDA, RDA 1395034931

3. Jeong DU, Lee HO, Kim YK, Seo KH, Om AS (2016) Minerals(calcium, iron, zinc) analysis and interaction of emphasized nutrition indication on products. J Food Hyg Saf, 31, 420-425

4. Ji SH, Kang JH, Jo GS, Lee SK, Kim HR, Choi YM, Lee YS (2016) Comparison of ash and mineral contents in local agricultural products. Korean J Food Nutr, 29, 1015-1022

5. Kim JH, Kim MJ, Oh HK, Chang MJ, Kim SH (2007) Seasonal varoation of mineral nutrients in korean common fruits and vegetables. J East Asian Soc Dietary Life, $17,860-875$

6. RDA (2016) Korean food composition table. $9^{\text {th }}$ revision, Rural Development Administration, Wanju, Korea, p 3-7

7. Kim MG, Kim YS, Kim YS, Lee SB, Ryu KS, Yoon MH, Lee JB (2014) A study on the content of minerals in fortified food. J Fd Hyg Safety, 29, 99-104

8. Kim SD, Moon HK, Park JS, Yang HR, Yi YJ, Han EJ, Lee YC, Shin GY, Kim JH, Chae YZ (2012) The content of macrominerals in beverages, liquid teas, and liquid coffees. J Korean Soc Food Sci Nutr, 41, 1134-1143

9. Kim TR, Whang HJ, Yoon KR (1996) Mineral contents of korean apples and apple juices. Korean J Food Sci Technol, 28, 90-98

10. Kim MS, Yang HR, Jeong YH (2004) Mineral contents of brown and milled rice. J Korean Soc Food Sci Nutr, 33, 443-446

11. Kim CT, Cho SJ, Hwang JK, Kim CJ (1997) Composition of amino acids, sugars and minerals of domestic wheat varieties. J Korean Soc Food Sci Nutr, 26, 229-235

12. Seo JS, Jeong EJ (1992) A study on mineral content 
in processed foods. Korean J Food Nutr 5, 104-110

13. Hong YS, Kim KS (2017) Effect of cooking methods on elemental composition of pumpkin (Cucurbitaceae spp.). J Korean Soc Food Sci Nutr, 46, 1195-1204

14. Lee JS, Kim SG, Kim CS, Cho MH (1983) Contents of minerals and amino acid of husked and naked barley. Korean J Food Sci Technol, 15, 90-92

15. Cha MA, Oh MS (1996) Changes in mineral content in several leaf vegetables by various cooking methods. Korean J Soc Food Sci, 12, 34-39

16. Oh MS (1996) Changes in mineral content in several root vegetables by various cooking methods. Korean $\mathrm{J}$ Soc Food Sci, 12, 40-45

17. Chang KM, Lee MS (2000) Mineral contents of underground vegetables produced in different regions of korea. J Soc Food Sci, 16, 425-430

18. KFDA (2019) Korean Food Standards Codexs. Korean Food and Drug Administraion

19. Codex Alimentarius International Food Standards (2019) Guidelines on performance criteria for methods of analysis for the determination of pesticide residues in food and feed. CAC/GL 90-2017

20. AOAC (2005) Official methods of analysis. Association of Official Analytical Chemists, Washington, DC, USA. Method 985.35

21. Gyeongsangnam-do Agricultural Research \& Extension Services reference Room : https://www.gnares.go.kr: 8444/Home//BBSList.mbz?action=MAPP_0000000033\&s chIdx $=0 \&$ schCategorycode $=\&$ schKeytype $=$ subject\&schKe yword $=\% \mathrm{EA} \% \mathrm{~B} 8 \% 88 \% \mathrm{EC} \% 8 \mathrm{~B} \% \mathrm{~A} 4 \&$ pageIndex $=1$
22. Ahn HJ, Son HS (2012) Physicochemical properties of different grape varieties cultivated in korea. Korean $\mathrm{J}$ Food Sci Technol, 44, 280-286

23. Chungcheongbuk-do Agricultural Research and Extension Services reference Room: hitp://ares.chungbuk go.kr/home/sub.php? menukey $=1185 \&$ mod $=\&$ page $=2 \&$ scode $=00000002$

24. Ikebe K, Nishimune T, Tanaka R (1990) Contents of 17 metal elements in food determined by inductively coupled plasma atomic emission spectrometry. J Food Hyg Soc Japan, 31, 382-393

25. Kim SD, Moon HK, Park JS, Lee YC, Shin GY, Jo HB, Kim BS, Kim JH, Chae YZ (2013) Macromineral intake in non-alcoholic beverages for children and adolescents: using the fourth korea national health and nutrition examination survey. Korea J Nutr, 46, 50-60

26. Choi MK, Hyun WJ, Lee SY, Park HJ, Kim SN, Song $\mathrm{KH}$ (2010) One portion size of foods frequently consumed by Korean adults. Nutr Res Pract 4, 82-88

27. Korea Centers for Disease Control and Prevention (2011) Raw data of the Fifth Korea National Health and Nutrition Examination Survey (KNHANES V-2), Korea Centers for Disease Control and Prevention. Cheongju, Korea

28. Kim SB, Kim SK, Kim SN, Choi YS, Kim MH (2013) Establishment of one portion size of dishes frequently consumed by Korean adults using 2010 KNHANES and its comparison with the one portion size using 2005 KNHANES-Focusing on rice, noodles, soups, and stews. Korean J Food Nutr 26, 745-752

29. Lee GI, Kim SH, Huk SY, Choi JH, Park IH (2018) Food Consumption Survey Basic Analysis Report. KREI E16-2018 